\title{
SIPEX 2012: Extreme sea-ice and atmospheric conditions off East Antarctica
}

\author{
P. Heil ${ }^{1,2}$, S. Stammerjohn ${ }^{3}$, P. Reid ${ }^{4}$, R.A. Massom ${ }^{1,2}$, J.K. Hutchings ${ }^{5}$ \\ ${ }^{1}$ Australian Antarctic Division, Kingston, Australia \\ ${ }^{2}$ Antarctic Climate and Ecosystems CRC, University of Tasmania, Hobart, Australia \\ ${ }^{3}$ University of Colorado, Boulder, USA \\ ${ }^{4}$ Bureau of Meteorology, Hobart, Australia \\ ${ }^{5}$ Oregon State University, Corvallis, USA
}

\begin{abstract}
In 2012, Antarctic sea-ice coverage was marked by weak annual-mean climate anomalies that consisted of opposing anomalies early and late in the year (some setting new records) which were interspersed by near-average conditions for most of the austral autumn and winter. Here, we investigate the ocean-ice-atmosphere system off East Antarctica, prior to and during the Sea Ice Physics and Ecosystems eXperiment [SIPEX] 2012, by exploring relationships between atmospheric and oceanic forcing together with the sea-ice and snow characteristics. During August and September 2012, just prior to SIPEX 2012, atmospheric circulation over the Southern Ocean was near-average, setting up the ocean-ice-atmosphere system for near-average conditions. However, below-average surface pressure and temperature as well as strengthened circumpolar winds prevailed during June and July 2012. This led to a new record $\left(19.48 \times 10^{6} \mathrm{~km}^{2}\right)$ in maximum Antarctic sea-ice extent recorded in late September. In contrast to the weak circum-Antarctic conditions, the East Antarctic sector (including the SIPEX 2012 region) experienced positive sea-ice extent and concentration anomalies during most of 2012, coincident with negative atmospheric pressure and seasurface temperature anomalies. Heavily deformed sea ice appeared to be associated with intensified wind stress due to increased cyclonicity as well as an increased influx of sea ice from the east. This increased westward ice flux is likely linked to the break-up of nearly $80 \%$ of the Mertz Glacier Tongue in 2010, which strongly modified the coastal configuration and hence the width of the westward coastal current. The associated changed coastal configuration allowed more sea ice to remain within the coastal current at the expense of a reduced northward flow in the region around $141^{\circ}-145^{\circ} \mathrm{E}$. In addition a westward propagating positive anomaly of sea-ice extent from the western Ross Sea during austral winter 2012 has been identified to have fed into the westward current of the SIPEX 2012 region. A pair of large grounded icebergs appears to have modified the local stress state as well as the structure of the ice pack upstream and also towards the Dalton Glacier Tongue. Together with the increased influx of sea ice into the regions, this contributed to the difficulties in navigating the SIPEX 2012 region.
\end{abstract}

\section{Introduction}

In recent decades, sea ice in both polar regions has undergone significant yet contrasting change overall (although there are regional similarities [Stammerjohn et al., 2012]). In the Arctic, the loss of overall sea-ice extent in summer has accelerated to about $13 \%$ per decade relative to the 1981 to 2010 average [NASA, 2016] accompanied by substantial loss of multiyear ice [Kwok, 2007; Maslanik et al., 2011], leading to thinning of the sea-ice pack (e.g., Lindsay and Schweiger [2015]). These dramatic changes, which have been attributed to a complex combination of both thermodynamic and dynamic processes and associated 
feedbacks, have led to a less robust sea-ice cover that is more vulnerable to dynamic and thermodynamic forcing [Overland et al., 2012; Perovich, 2011; Rampal et al., 2009]. At the same time, the overall Antarctic sea-ice extent has exhibited a statistically significant (albeit weak) increasing trend of $+1.5 \%$ per decade for $1980-2014$ [Turner et al., 2015], but composed of high regional and seasonal variability [Holland, 2014; Turner et al., 2015]. Most outstanding are the sustained loss of sea ice in the Amundsen-Bellingshausen seas $(-6.8 \%$ per decade) and increasing sea-ice extent in the Ross Sea (+4.9\% per decade) [Turner et al., 2015]. Both coincide with similar sign regional changes in annual duration of the sea-ice cover, i.e., shortening of the sea-ice season by over 3 months in the AmundsenBellingshausen seas sector and lengthening by 2.6 months in the western Ross Sea [Stammerjohn et al., 2012]. Most recently, after successive ice-extent maxima from 2012 to 2014 [Reid and Massom, 2015], the 2015 maximum ice extent was close to the long-term average, possibly associated with the return of a well developed El Niño. Consequently, higher surface pressure and warmer surface air and sea-surface temperatures around the Western Antarctic may have been responsible for driving down the overall Antarctic sea-ice extent. In East Antarctica, the focus of this study, the patterns of change in sea-ice annual advance, retreat and duration are more complex, with regions of shortening and lengthening trends in sea-ice annual duration (of $\pm 2-3$ days/year) in juxtaposition [Massom et al., 2013b]. It is worth noting that for the East Antarctic there is no consistent response of sea-ice distribution to changing El Niño conditions [Stammerjohn et al., 2008].

The causes of the overall Antarctic sea-ice increase, and the regionally- and seasonallycontrasting contributions, are poorly understood, although a number of mechanisms have been proposed. Holland and Kwok [2012] suggest that wind-driven changes in ice transport and thermodynamics are the dominant drivers of ice-concentration trends off West Antarctica and all other Antarctic sea-ice regions, respectively. Other mechanisms proposed include: enhanced recent freshening and stabilisation of the ocean surface mixed layer [Bintanja et al., 2013] by accelerated basal melt of Antarctic ice shelves [Pritchard et al., 2012]; increased precipitation [Liu and Curry, 2010]; seasonal thermal ocean-ice feedback [Stammerjohn et al., 2012]; and feedback between changes in the high-latitude Southern Ocean and atmosphere [Zhang et al., 2007]. Current lack of consensus as to what is driving observed patterns of Antarctic sea-ice change and variability underlines the complexity of the Antarctic air-sea-ice interaction system set against a lack of observations. It also points to the urgent need for improved understanding of the processes involved and how they are changing around Antarctica. This is, in turn, a key prerequisite to improving climate-model performance and predictive capability [Turner et al., 2015]. Particularly important in this regard is treatment of sea-ice seasonality as well as extent, concentration and thickness.

An impediment for our understanding of how and why Antarctic sea ice is changing, and our confidence in model projections of its future response, is that (compared to the Arctic) there are few sea-ice and snow-cover thickness observations for the Southern Hemisphere [Maksym et al., 2012]. Current knowledge is limited to in situ and ship-based datasets that are limited in both space and time [e.g., Heil, 2006; Massom et al., 2001; Ozsoy-Cicek et al., 2011; Worby et al., 2008]. This issue is exacerbated by the difficulty of obtaining accurate large-scale thickness information from satellites in Antarctica. Compared to the Arctic, Antarctic sea ice is characterised by near-zero freeboard and extensive surface flooding [Maksym and Markus, 2008] that significantly increase the difficulty of deriving ice thickness 
from satellite altimetry [Kern and Spreen, 2015; Lubin and Massom, 2006]. Moreover, techniques using radar altimetry require independent information on snow thickness and density, and lack of information on spatio-temporal variability in these quantities contributes to current large uncertainty in derived ice-thickness estimates. As a result of these factors, few satellite-derived ice-thickness datasets are available (i.e., Xie et al., 2013; Zwally et al., 2008), and they remain largely unvalidated.

As background, sea-ice coverage in this sector of East Antarctica is strongly seasonal and occupies a relatively narrow zone that extends from the coast (at about $66^{\circ}-67^{\circ} \mathrm{S}$ - relatively far north) to about $60^{\circ}-62^{\circ} \mathrm{S}$ at maximum extent [Gloersen et al., 1992; Massom et al., ]. As shown by Massom et al. [2013b, Fig. 1], the climatological patterns of annual advance, retreat and duration of the sea-ice pack in this sector of East Antarctica largely mirror the broadscale ocean bathymetry, with increased meridional extent to the immediate west of the SIPEX 2012 region. Regional oceanic circulation and thus patterns of sea-ice drift, both within and into/out of the region, are dominated by the eastward-flowing Antarctic Circumpolar Current $[A C C]$ to the north and the westward-flowing Antarctic Coastal Current or East Wind Drift that skirts the continental margin to the south [Heil and Allison, 1999]. These two major current regimes are separated by the Antarctic Divergence, with meridional pathways (mainly northward retroflections) in ice drift occurring near $110^{\circ}, 125^{\circ}$ or $135^{\circ} \mathrm{E}$ [Heil and Allison, 1999]. While the Antarctic Divergence itself undergoes a seasonal north-south relocation [Heil and Allison, 1999], the relative latitude of the ice edge to that of the Antarctic Divergence provides feedback into the northward expansion of the sea-ice cover. During low ice extent in summer to mid autumn, the northern ice edge remains well south of the Antarctic Divergence, and hence the zonal ice transport is solely to the west, with the mean zonal deviations largely depending on barotropic ocean currents. As the ice edge advances northward of the Antarctic Divergence, ice in the eastward flow there experiences a slight northward deflection due to Coriolis forcing, which provides a positive feedback to the equatorward expansion of the ice pack.

Although narrow (to about $550-700 \mathrm{~km}$ ) and with considerable interannual variability, the sea-ice zone in the region of interest is highly dynamic, with synoptic-scale transient atmospheric low-pressure systems driving strong ice deformation and precipitation events causing considerable spread in the sea-ice and snow-cover thickness distributions [Heil and Allison, 1999; Toyota et al., 2016]. Moreover, the ice pack comprises a number of distinct zones with different morphological characteristics [Massom and Stammerjohn, 2010]. These are (from north to south): i) the highly-dynamic marginal ice zone where sea ice characteristics and processes are strongly affected by wave-ice interaction; ii) the inner pack, characterised by larger floes and thicker snow cover; and iii) the near-coastal and coastal zones, which are strongly affected by interaction with the ice sheet margins and icebergs that ground in waters shallower than $450 \mathrm{~m}$. The latter element also comprises polynyas and fast ice, including an area of fast ice in the embayment to the west of the Dalton Iceberg Tongue that regularly breaks out to feed ice into the coastal current [Heil et al., 2011]. SIPEX 2012 largely sampled ice from the inner and near-coastal zones.

Here, we analyse new information on the ocean-sea ice-snow-atmosphere system off East Antarctica acquired during SIPEX 2012. This study was conducted on the icebreaker RSV Aurora Australis in the late winter-early spring of 2012 (22 September to 11 November) off the 
Wilkes Land coast and in the region bounded by $63^{\circ}-66^{\circ} \mathrm{S}$ and $117^{\circ}-121^{\circ} \mathrm{E}$. A region that was also the focus of two previous experiments i.e., ARISE in 2003 [Massom et al., 2006] and SIPEX 2007 [Worby et al., 2011], enabling direct comparison of sea-ice conditions in those years. Details of the experimental sites for SIPEX 2012 are given in Meiners et al. [2016, Fig.1], while Toyota et al. [2016] provide a detailed analysis of the coincident snow conditions. An overriding feature of SIPEX 2012 is the apparent extremity of ice conditions compared to previous years sampled, with a predominance of thick and heavily-deformed first-year ice (with maximum thicknesses peaking around $15 \mathrm{~m}$ [Williams et al., 2015]). The snow cover was also unusual, in that its average depth of $0.45 \mathrm{~m}$ was almost three times that observed in the region between 1992 and 2007 [Toyota et al., 2016]. Here, we combine in situ, satellite, meteorological and other data to investigate how local and regional ocean-ice-atmosphere interactions (including icebergs) shaped the sea-ice conditions encountered prior to and during SIPEX 2012, and to place the SIPEX 2012 findings in a circumpolar Antarctic context. We then carry out a comparison with results from other years to put the apparent extremes observed during SIPEX 2012 into longer-term context.

\section{SIPEX 2012: Data and Methods}

3.

SIPEX 2012 occupied the off-shelf region north and west of the Dalton Glacier Tongue (Fig. 1a), overlapping with the western part of the SIPEX 2007 region [Worby et al., 2011]. Difficult ice conditions in 2012 led to two very distorted north-south transects through the pack. In this study, we combine in situ data acquired during a total of eight ice stations deployed during SIPEX 2012 with various satellite and meteorological data to carry out a detailed analysis of sea ice and associated environmental conditions in the lead up to and during SIPEX 2012. Three distinct sea-ice regimes were encountered, with the latter two being sampled. The relatively small number of sampling sites is indicative of the difficult and somewhat extreme sea-ice and snow cover conditions encountered. Entry into the sea-ice zone (at $61.5^{\circ} \mathrm{S}$, $121.0^{\circ} \mathrm{E}$ ) was via loose pack within the wave-affected Marginal Ice Zone [MIZ] comprising brash ice and small floes (regime 1), while the bulk of SIPEX 2012 was spent within highly deformed first-year ice covered by an unusually thick snow cover [Toyota et al., 2016]. The northern part (regime 2) was characterised by relatively loose pack ice comprising mainly small floes with some level ice, while further to the south and west, the sea ice was under considerable pressure and free movement was restricted (regime 3 ). Unfortunately, no data are available from station 1 (at the transition of regimes 1 and 2) as it had to be abandoned when the ice floe broke up rapidly due to wave-induced flexure. Ice stations 2 to 4 occupied regime 2, while the later stations were sampled in regime 3 . In the lead up to the 10 day entrapment of RV Aurora Australis in regime 3 (ice station 8), the vessel had little freedom of movement within the pack. Hence, ice stations 6 and 7 , and 7 and 8 were separated by a few kilometres only (on a Lagrangian reference grid). With ice pressure relaxing, the vessel was finally able to free itself from the ice on 8 November 2012 (at $64.32^{\circ} \mathrm{S}, 114.43^{\circ} \mathrm{E}$ ), before traversing northward through ice regime 1 and departing the sea ice on 11 November 2012 at $60.95^{\circ} \mathrm{S}, 117.56^{\circ} \mathrm{E}$.

For each ice station, the objectives for sampling of ice- and snow-physics parameters were the same. Typically, a $100 \mathrm{~m}$ transect would be sampled at $1 \mathrm{~m}$ intervals for ice- and snow thickness, ice freeboard and detailed in situ observations. Time allowing, a second $100 \mathrm{~m}$ transect would be occupied perpendicular to the first one and framing the sampling array for 
two underwater vehicles. Full length ice cores were taken and detailed snowpits were carried out at 3 locations along the transect, generally at 0,50 and $100 \mathrm{~m}$. The ice cores provided vertical temperature as well as salinity and density profiles, from which brine volumes were derived. Oxygen isotope profiles revealed the presence of snow ice within the ice core and stratigraphic analysis of thin sections supported the interpretation of ice formation and thickening processes at play during 2012. Integration of oxygen isotopes from the structural ice cores taken during SIPEX 2012 indicates that snow ice occupies $4-8 \%$ of the total ice column. Vertical profiles of ice density [Hutchings et al., 2015] provide invaluable information required to convert (total) freeboard observations (such as from airborne or space-borne altimeters) into ice thickness. Detailed information on snow properties, thickness and precipitation is given in Toyota et al. [2016]. Ice-core data only are available from station 4, which was deployed on a small and highly ridged ice floe with a heavy snow load, and limited transect data were obtained during station 8 , where the vessel was beset.

While the ship was moving through the ice, hourly ship-based ice observations using the Antarctic Sea Ice Processes and Climate [ASPeCt] protocol [Worby and Allison, 1999; Worby et al., 2008] were recorded from the ship's bridge to characterise the sea ice within $1 \mathrm{~nm}$ of the vessel. Together with the in situ sea-ice measurements, these data are invaluable to characterise the ice and snow-cover conditions in the study region.

Broad-scale information on change and variability in regional sea ice concentration and extent in the lead-up to and during SIPEX II was derived from the NASA Bootstrap satellite-passive microwave product obtained from NSIDC (Comiso, 1999, updated), and for the interval 1979 to 2014. We also examined patterns of annual days of sea-ice advance and retreat and resultant duration of sea-ice coverage in the region for the sea-ice year (15 February to 14 February of the following year), based on tracking of the ice-edge positions (demarcated by a $15 \%$ ice concentration threshold) using the technique described in Stammerjohn et al. [2008]. Higher-resolution information on regional sea-ice coverage and characteristics was derived from Terra and Aqua MODIS visible and thermal infrared imagery, which provided synopticscale snapshots at $250 \mathrm{~m}$ resolution (but only when cloud-free).

Coincident information on daily sea-ice motion at $25 \mathrm{~km} \times 25 \mathrm{~km}$ resolution was obtained from the NSIDC passive microwave data product derived using maximum cross-correlation [Fowler, 2003]. In addition, autonomous drifting sea-ice GPS buoys [Heil, in prep.] provided higher temporal and spatial resolution information on ice drift and deformation within the SIPEX region. In order to investigate the possible effect of icebergs on sea-ice conditions, we compared this buoy information with iceberg position and motion data from the BYU satellite radar scatterometer enhanced-resolution product [Stuart and Long, 2011]. Furthermore, the impact of large icebergs on local and wider scale sea-ice conditions was investigated using a series of MODIS images.

Measurements of local meteorological and oceanic parameters were taken every 10 seconds by sensors on the RV Aurora Australis. Observed parameters include near-surface atmospheric (dry and wet) and water temperatures, wind velocity, atmospheric pressure, radiation fluxes, and sea-surface temperature and salinity. These underway data were supplemented by satellite and reanalysis data. To obtain information on sea-surface temperature [SST] conditions in the open ocean around the study region, we analysed the 
NOAA SST version 2 dataset [Reynolds et al., 2002; Smith et al., 2008], with SST anomalies from 2012 relative to the 1981-2010 mean being obtained using the NOAA Optimum Interpolation technique. To explore the impact of short-term (or synoptic) changes on sea-ice distribution (e.g., Kriegsmann and Bruemmer [2014]), we used cyclone statistics derived from the Automatic Cyclone Tracker technique [Murray and Simmonds, 1991] applied to 6-hourly mean sea-level pressure data from the ERA-Interim reanalysis $(1979-2015)$. The cyclone tracker searches for a grid point maximum of the Laplacian of air pressure, following Simmonds and Keay [2000]. The pressure minima are located by iteration from the local maxima using ellipsoidal minimisation techniques. Only pressure systems that satisfy the minimum concavity criterion [Simmonds, 2003], which ensures that they are of meteorological significance, were considered in this analysis.

\section{Results}

In order to understand the sea-ice characteristics encountered during SIPEX 2012 and their causes, we combine and synthesize the various datasets to assess local and regional ice conditions in concert with atmospheric and oceanic parameters. While the focus is on the immediate SIPEX 2012 region $\left(63^{\circ}-66^{\circ} \mathrm{S}, 117^{\circ}-121^{\circ} \mathrm{E}\right)$, the results are also examined within the wider East Antarctic $\left(56.0^{\circ}-69.5^{\circ} \mathrm{S}, 90^{\circ}-150^{\circ} \mathrm{E}\right)$ and circum-Antarctic context. Of particular interest is not only the experimental timeframe (September - November 2012) itself, but also the pre-conditioning that occurred during the preceding autumn and early winter in 2012. Hence, both synoptic and seasonal time scales are investigated here.

\subsection{Atmospheric forcing and sea-ice response prior to and during SIPEX 2012}

During April and May 2012, the monthly-averaged ice edge and ice concentration in the region of interest closely followed the long-term mean distribution (Fig. 2a-b). However, beginning in late June 2012 and clearly identifiable during July to September 2012, both the ice edge (denoted by the $15 \%$ concentration isopleth, Fig. 2c-f) and also the northern boundary of the inner pack (denoted by the $75 \%$ isopleth) in the SIPEX 2012 region were well to the north of their long-term $(1980-2012)$ mean positions. This contributed to a new historic record (since superseded) in Antarctic maximum sea-ice extent $\left(19.48 \times 10^{6} \mathrm{~km}^{2}\right)$ obtained on 26 September 2012 [Massom et al., 2013a].

The displacements of ice-concentration isopleths corresponded directly to the prevailing surface wind directions. During August and September (Fig. 2e and f) for example, strong winds with a southerly component pushed the ice concentration isopleths northward over the SIPEX 2012 region and west of there, while strong northerly winds to the east of SIPEX 2012 pushed the ice-edge southward (particularly in August). During October to December 2012, regionally weakening winds (see Fig. 6.2 in Wovrosh et al. [2013]) allowed the ice edge to retreat southward, but not as far south as the long-term mean. The surface winds during August and September are a reflection of the seasonal distribution of mean sea-level pressure off East Antarctica - with a stationary high, centred near $90^{\circ} \mathrm{E}$ and to the north of the pack ice [Wovrosh et al., 2013], giving rise to excessive northward ice advection during the 2012 austral winter compared to the long-term mean.

Of great interest is the extraordinary northward relocation of the $75 \%$ isopleth, which we interpret as the transition from the marginal ice zone to the more consolidated pack proper. From July to September 2012 and in the SIPEX 2012 region, the inner pack occupied about 
twice the meridional extent of its long-term mean. This increase in consolidated pack ice coincides with winds blowing from the southeast over most of the SIPEX 2012 region (and to its south). Interestingly, these winds were not that anomalous for July and August compared to the 1980 to 2012 mean, while in September these prevailing southeasterly winds were actually somewhat weaker than normal. However, there was an anomalous increase in the influx of sea ice from the east throughout this time period that most definitely contributed to the anomalous compaction of sea ice in the inner pack ice zone between $108^{\circ}$ and $122^{\circ} \mathrm{E}$ by October 2012. This will be discussed in greater detail further below.

The increased winter ice extent in the wider SIPEX region $\left(115^{\circ}-130^{\circ} \mathrm{E}\right)$ closely followed the mean circum-Antarctic increase in 2012 [Massom et al., 2013b; Reid et al., 2015]. The above average circum-Antarctic winter sea ice extent was associated with strengthened circumpolar winds and a positive phase of the Southern Annular Mode [Wovrosh et al., 2013]. To evaluate the 2012 sea-ice extent against the full observational record $(1979-2012)$ for the SIPEX region, the 34-year trends of ice extent and its derived parameters have been calculated (Tab. 1). The 34-year trend in sea-ice extent, up to and including 2012 and for the SIPEX 2012 region (box), was about $+0.4 \%$ per year, but with high interannual variability (Tab. 1). Especially in 2012, ice extent there underwent a considerable increase above the long-term mean. This was supported by an earlier expansion during autumn (Fig. 3a), which set this region up for a longer Ice season duration. With sea-ice retreat at the end of the season also being delayed over most of the region (from $\sim 100^{\circ}$ to $190^{\circ} \mathrm{E}$; Fig. 3b), the ice season was anomalously longer by 1 to 3 months (Fig. 3c). Interestingly, the 36-year trend in ice season duration for the northern part of the SIPEX region (Fig. 3d) depicts a negative trend of $~ 20$ days/decade (which stands in contrast to the region-wide weak positive trend of +5 days/decade; Tab. 1). In circum-Antarctic context, apart from the Bellingshausen/Amundsen seas, the Marginal Ice Zone of the wider SIPEX region and the intensified Prydz Bay Polynya are the only Antarctic areas, where ice season duration shows a negative trend over the satellite record. In contrast to these strong negative to slightly positive local ice trends, SIPEX 2012 coincided with extreme positive sea ice anomalies throughout the SIPEX region (as illustrated in Fig. 2c). Compared to trends reported in our analysis of SIPEX 2007 (Stammerjohn et al., 2011), these updated regional sea ice trends (computed over 1979-2012 versus 1979-2007) are slightly more positive and support the interpretation that the inner pack ice (as identified by ice concentrations above $75 \%$ ) has become more extensive, together with the overall ice edge. A further contributor to the increased ice extent and concentration in the SIPEX 2012 region will be discussed in the next section.

\subsection{Linkages between sea ice and upper ocean during 2012}

Here, we explore apparent relationships between regional anomalies in sea-surface temperature and sea-ice distribution, including the annual sea-ice advance, retreat and duration. Early in 2012, there was anomalously high sea-ice concentration (compared to the long-term mean) in the eastern Weddell Sea, far western East Antarctica (Fig. 4, 1st row) and western Ross Sea and to a lesser degree off the coast in the Amundsen-Bellingshausen seas (see Massom et al. [2013a]). At this time, these regions exhibited not only cooler surface air temperatures (compared to the long-term mean) but also reduced summer SSTs. By austral autumn 2012, the sea-ice anomalies off East Antarctica had moderated (Fig. 4, 2nd row), and in austral winter 2012, the distribution of ice-concentration/extent anomalies closely tracked SST anomalies (Fig. 4, 3rd row), with substantial increases in sea-ice extent across the 
extended SIPEX 2012 region $\left(100^{\circ}-145^{\circ} \mathrm{E}\right)$ as well as in the eastern Ross Sea (not shown). Around the remainder of Antarctica, SSTs in the Southern Ocean followed the long-term values with few positive (warmer) and negative (cooler) anomalies during austral winter 2012. In austral winter 2012, the only remaining pools of anomalously-cold SST were located off East Antarctica (barely protruding north of the ice edge) and the eastern Ross Sea (protruding substantially further north of the ice edge).

Moving into spring and early summer 2012 (Fig. 4, 4th row), the sea ice off East Antarctica largely followed the annual retreat pattern, although the remaining near-coastal sea ice exhibited higher than normal ice concentration, especially during December 2012. This coincided with above-average surface pressure (anomaly to $+1.8 \mathrm{hPa}$ ) and surface air temperature (anomaly to $+1.9^{\circ} \mathrm{C}$ above the mean), as well as increased standard deviation anomalies, for the East Antarctic Ice Sheet plateau and the neighbouring sea-ice zone, as revealed in ECMWF reanalysis data. These atmospheric changes were reflected in the regional sea-ice conditions during December, which coincided with the only month in 2012, when Antarctic ice extent was below the long-term average.

\subsection{Sea-ice fluxes and large icebergs}

During 2012, monthly mean sea-ice velocities off East Antarctica (Fig. 5) depict the typical evolution with an equatorward expanding autumn ice cover that culminates with a fullydeveloped ice circulation at maximum ice extent. The sea-ice circulation includes i) a westward moving band, which occupies the continental shelf and extends some distance to the north of the shelf break; and ii) a discontinuous eastward return flow, which occupies most of the northern regions from late autumn to mid spring. These two zonal bands are connected by meridional jets, which during July to September 2012 formed recirculation cells (i.e., clockwise gyres centred on $103^{\circ} \mathrm{E}$ or $115^{\circ} \mathrm{E}$ ), similar to those documented previously by Heil and Allison [1999]. The western limbs of these gyres contribute to the northward movement of sea ice to the north of the Antarctic Divergence, hence affecting the magnitude of northward ice-edge anomalies. The easterrn limbs, on the other hand, give rise to southward motion and convergence which impacts regional ice desoformation and thickness. Near-circular pathways have also been identified in a numerical model [Bintanja et al., 2015], where southward ice drift gives rise to dynamical thickening at times of extensive sea ice.

As these structural elements of the East Antarctic sea-ice cover evolved during 2012, so did the regional pattern of sea-ice motion. Ice-motion magnitude also exhibits a seasonal pattern with increased daily mean ice motion during autumn, followed by a slight reduction during June and July coinciding with increasing ice concentration. As recirculation cells form, the mean ice motion reaches its minimum during August. Around the time of maximum ice extent (late September) the ice motion picks up again.

In the following, the interannual variability of East Antarctic sea-ice motion is explored using passive microwave data $(1979-2015)$. We found that the coastal westward flux of sea ice across $138^{\circ} \mathrm{E}$ was enhanced during recent years (including 2012) compared to preceding years. This enhanced westward ice transport coincided with a reduced zonal ice flow north of the Mertz Glacier region $\left(145^{\circ} \mathrm{E}\right)$. This change in ice transport is likely a consequence of the 2010 major calving event of the Mertz Glacier Tongue [Schmaltz, 2010]. With the northern section of the glacier tongue gone, bathymetric steering of the sea-ice pack led to greater 
retention of ice to the south of the Antarctic Divergence. In 2012 this resulted in increased ice convergence (and rafting and thickening) in the southern part of the SIPEX 2012 region.

Furthermore, weekly passive microwave-derived ice motion was combined with iceconcentration data to derive the meridional and zonal ice fluxes at $135^{\circ} \mathrm{E}$ and $138^{\circ} \mathrm{E}$. The flux is the product of the ice motion and concentration accumulated for all grid cells along the flux gate normalied by the area of each grid cell. Fluxes are separated into meridional (Fig. 6a) and zonal (Fig. 6b) components. In 2012, the increased westward ice flux (Fig. 6a) is accompanied by a reduction in northward export from the area (Fig. 6b), likely leading to increased deformation, including dynamic thickening, as the band of ice moved towards the Dalton Glacier Tongue. This is an area where the westward sea-ice current is constricted in latitude by bathymetric steering as well as coastal features. In a year of extreme sea-ice conditions such as 2012, an elevated westward ice transport led to extraordinary deformation in the near-coastal zone, including ice-floe break-up as well as extensive ridge building as observed in the SIPEX 2012 region.

For SIPEX 2012, we also investigated the effect of large icebergs on the local sea-ice cover and motion. In 2012, large icebergs B09F, B09G and C18B drifted through our region of interest along the continental shelf and within the westward coastal current. Other icebergs remained grounded during 2012, including B16 and C28B, while others could be found following the shelf break to the north, such as B09D. Measuring $50 \mathrm{~km}$ by $9 \mathrm{~km}$, B09D arrived seven days prior to our research vessel at the southern edge of the SIPEX 2012 voyage trajectory, moving ahead of the vessel by about $60 \mathrm{~km}$ to the west. B09D followed the continental shelf break closely at a speed slightly (3\%) faster than the RV Aurora Australis, the latter passively drifting with the ice pack. Drifting buoys provide ice velocity from just to the north of B09D, and the motions of both are in close agreement (Fig. 7), suggesting that these drifting icebergs played a minimal role in affecting the larger-scale (more extensive) ice deformation observed.

\subsection{Shear state of the SIPEX 2012 sea ice}

The ASPeCt data acquired during SIPEX 2012 show a dominance of deformed first-year ice with very few vast (diameter in excess of $2000 \mathrm{~m}$ ) and only some large $(500-2000 \mathrm{~m}$ diameter) floes. Multi-year ice floes, which constituted only $\sim 5 \%$ of the overall ice coverage, were mostly small or medium i.e., similar in size to the deformed first-year ice. This is in contrast to previous observations from the region. For example, during SIPEX 2007, deformed (first-year) ice was very localised and generally associated with discrete, synopticscale events [Heil et al., 2011]. In 2007, a distinct shear line was identified as a nearstationary feature associated with the continental shelf break and the narrow slope jet [Heil et al., 2011]. During SIPEX 2012, the complete ice cover in the southern-most area (i.e., regime 3) was under considerable pressure, limiting free ice drift. By early November 2012 two shear lines emanated eastward from the north-eastern tip of B16 that was beset on the shelf to the west of the SIPEX 2012 trajectory. One arched into the Dalton Polynya, while the other mostly connected to the northern end of the Dalton Ice Tongue or propagated to its north-east (Fig. 1c). This was a significant change compared to earlier (04. Oct. 2012) during SIPEX 2012 when there was only a single shear line (Fig. 1b). The stress state of the pack ice upstream (i.e., eastward) of the large grounded icebergs was altered (compared to times when there were no grounded icebergs in that area), due to apparent increased shear and 
deformation in the ice, as also shown in coincident MODIS imagery of the region (Fig. $1 \mathrm{~b}$ and c).

\subsection{Cyclone statistics during SIPEX 2012}

For the SIPEX 2012 region, repeated short-term circulation changes brought lower than usual surface air pressure during January, June and July 2012, consequently strengthening the zonal (surface) winds, particularly in July (e.g., Figure 2d). In 2012, centres of increased cyclolysis (not shown here, but indicates that an increase number of cyclones moved into this region, stalled and dissipated) were found off Enderby Land $\left(45^{\circ}-60^{\circ} \mathrm{E}\right)$, over Prydz Bay $\left(75^{\circ} \mathrm{E}\right)$ and at the coast off Wilkes Land at $110^{\circ} \mathrm{E}$. In the latter region in 2012, anomalies in cyclone density peaked during June, July, August and October (Fig. 8). Similarly, in the Ross Sea positive anomalies in cyclone activity gave rise to reductions in the distribution of the mean central pressure for several months during 2012, implying that both these regions were preferred locations for cyclolysis.

\section{Discussion}

The observed response of Antarctic sea ice to a warming climate on Earth, especially in the polar regions [Taylor et al., 2013], challenges our skill to predict its future evolution. While East Antarctic sea-ice extent overall exhibits a small but consistent increase since 1979, in 2007 (then the second highest maximum ice extent after 2006 in the $1979-2007$ record) the SIPEX region occupied an area of large negative anomaly in sea-ice extent (i.e., reduced ice extent). In contrast during 2012 the SIPEX region harboured one of the only two positive iceextent anomalies in the Southern Ocean (the other being in the Eastern Ross Sea). Antarctic sea-ice extent is driven by external forces, mainly by surface winds and ocean forcing (i.e., heat fluxes and currents) with surface ocean and atmosphere temperatures, snow cover and ice kinematics determining the structural composition of the sea ice. Here, we draw together our investigation of the East Antarctic ocean-ice-atmosphere processes to identify contributors to the extreme ice conditions in the SIPEX region during 2012.

\subsection{SIPEX 2012 sea-ice conditions within the Antarctic climate system}

Atmospheric reanalysis data from 1979 to 2012 reveal positive trends in wind-speed, which are also consistent with station based trends from Sub-Antarctic islands [Hande et al., 2012 updated; Yang et al., 2007]. While there is evidence of this strengthening of the zonal mean westerly wind-stress jet in the Southern Hemisphere, there has not yet been any firm evidence for an annual mean shift in the position of the jet over the historical period [Swart and Fyfe, 2012]. Focussing on conditions prior to, during and post SIPEX 2012, the positive SAM during January, June and July 2012 [Massom et al., 2013a; Wovrosh et al., 2013] was synonymous with strengthened zonal surface winds around Antarctica compared to the longterm mean. The seasonally-averaged SAM index was positive from December 2011 to October 2012. This coincided with a southward shift of the circum-Antarctic trough. From then onwards, and due to a positive surface pressure anomaly over the AmundsenBellingshausen seas, SAM swung to negative for November and December 2012. Nevertheless, surface pressure remained below the long-term mean for the regions off East Antarctica during 2012. Similar to a weak zonal wavenumber [ZW]-3 pattern, the anomalies of higher than normal pressure over the Amundsen-Bellingshausen seas contrasted with belowaverage pressure in the southern Atlantic, Indian and Pacific oceans during September to December 2012. This forced the trough further to the north in those regions, leading to a 
slight positive anomaly in sea-ice extent. However, by November 2012 and lasting into December 2012, weaker than normal circumpolar winds allowed the circumpolar trough to relax southward and also brought warmer surface conditions. Consequently the sea-ice edge retreated swiftly and yielded below-average December ice extent in the region (see also Massom et al., 2013a).

Off East Antarctica, increased sea-ice concentrations across the retreating ice pack during austral spring (Fig. 4, 4th row) coincided with a persistent delay in sea-ice retreat at the end of the season. Recently, increased ice concentration and delayed sea-ice retreat have coincided with cooler surface waters in the area [Reid et al., 2015]. These regional changes in the oceanic mixed layer are likely to be forced by an intensified wind stress curl linked to a poleward shift in the circumpolar westerly winds associated with the changes in the SAM. Variability in the SAM is linked to a long-term delay in the sea-ice advance over the SIPEX region (of -0.34 days $\mathrm{yr}^{-1}$ ). However, SSTs off East Antarctica (and the Ross Sea) in 2012 were cooler than usual and the northward expansion of sea ice resumed early after a shorter than usual summer season, suggesting pre-conditioning of the 2012 sea ice by events from the previous season. As for a mechanism for such a cold pool, Liu and Curry [2010] previously suggested increased precipitation for the region. However, Toyota et al. [2016] concluded from their analysis of reanalysis data that 2012 did not exhibit an increase in net precipitation (based on the record from 1990 to 2012), neither for the SIPEX region nor for East Antarctica as whole. Consequently, additional cold water might have arrived from an unknown source other than precipitation.

\subsection{A region of variability: SIPEX 2007 versus SIPEX 2012}

Here, we investigate how the concurrent short-term state of the near-surface atmosphere might help to explain differences in sea-ice conditions observed between SIPEX 2007 and SIPEX 2012. To do so, we discuss the cyclone distribution for 2012 (the one for 2007 is presented in Stammerjohn et al. [2011]), with a view to exploring the marked differences in sea-ice characteristics encountered between the two field experiments.

The poleward movement of the circumpolar trough during positive phases of SAM brings a larger number of cyclone trajectories further south. In the East Antarctic, where they interact with coastline, cyclolysis peaks [Uotila et al., 2013]. To explore if and how changes in cyclolysis may have contributed to the more extensive and persistent sea-ice cover over a wide swath off Wilkes Land, we investigate its influence on the ocean-ice-atmosphere system in the lead up and during SIPEX 2012. In the higher latitudes, low-pressure (or synopticscale) systems drive much of the short-term ( $3-8$ day) variability in the atmospheric system. In general, the cyclone distribution interacts with the Antarctic Circumpolar Trough, with lowpressure systems mostly arriving from one of the two dominant centres of cyclogenesis in the mid latitudes off Prydz Bay [Jones and Simmonds, 1993]. Overall, the cyclone density distribution exhibits little variability at seasonal scales, while central pressure of the systems undergoes a semi-annual modulation (e.g., Jones and Simmonds [1993]).

In the SIPEX 2012 year, the persistent southward dislocation of the westerly wind stream lasted until about August/September. Intensification of the near-surface winds in the coastal region off East Antarctica in 2012 was likely to have affected the regional sea ice via a secondary mode. The observed stronger winds (Fig. 2) not only increased the sea-ice velocity 
but were also likely to have given rise to increased sea-ice deformation compared to previous years (see also Toyota et al. [2016]). In 2012, synoptic-scale circulation changes off the East Antarctic led to repeated episodes of ice-floe break up as well as intermittent convergence of the ice pack against the coastal (or fast-ice) boundary (both allowing for dynamic thickening) and, in general, by redistributing ice slabs into pressure ridges. Bridge-based ASPeCt as well as in situ observations from SIPEX 2012 revealed a highly deformed and thick ice pack of first-year ice, with ridged ice thickness exceeding $10 \mathrm{~m}$ [Williams et al., 2015]. Inclusions of snow ice at multiple depths within individual SIPEX 2012 ice cores were confirmed by oxygen isotope analysis. Comparison with equivalent measurements from SIPEX 2007 (11-18\%) [Worby et al., 2011] shows that the overall contribution of snow ice to the total ice column was less for SIPEX 2012 (4 - 8\%). This suggests that increased frequency of ice break-up and ridge-formation events due to increased cyclone density led to less time between break-up events for accumulation of snow.

\subsection{Influx from the east}

During SIPEX 2012, atmospheric and sea-ice conditions were important contributors to an extraordinary influx of sea ice into the region from the east and within the coastal current (Fig 5). This appears to have been facilitated by changes to the ice-sheet coastline upstream of the SIPEX 2012 region, due to the loss of much of the Mertz Glacier Tongue in early 2010. This enabled more sea ice to remain within the coastal westward current and to move into the SIPEX 2012 region than in previous years, when a significant amount of sea ice had been advected north across the Antarctic Divergence into the eastward conveyor of sea ice. On the larger scale, we find a likely link to the anomalously early sea-ice advance from the western Ross Sea across $150^{\circ} \mathrm{E}$ in 2012 (Fig. 9b) compared to 2007 (Fig. 9a), when the positive iceextent anomaly did not advance west of $150^{\circ} \mathrm{E}$. Together, these processes resulted in a very compact sea-ice cover moving from the east into the SIPEX 2012 region.

Once this stream of sea ice arrived within the SIPEX 2012 region, it encountered a zone of extraordinary high shear, locally magnified by the apparent grounding of two vast icebergs downstream from the Dalton Iceberg Tongue and at the transition zone from a narrow to a wider coastal current. Consequently, constriction occurred in the passage of the stream of sea ice, leading to back pressure, increased ice-floe break-up and more extensive ridge formation in the near-coastal zone in 2012 (compared to 2007). We note the possible additional contribution of wave-induced ice-floe break-up, due to storm-generated ocean waves propagating through sea ice for several hundred kilometres [Kohout et al., 2014], hence well into the SIPEX 2012 study region. The kinematic energy of the incoming waves was eventually dissipated by the fracture of ice floes into smaller units, as well as by ridge formation, highlighting the importance of waves not only for the marginal ice zone but also the wider sea-ice zone.

\section{Conclusions}

Changes in sea-ice extent around East Antarctica are largely driven by intensification of synoptic surface wind. During much of 2012, the band of westerlies that persistently blow around the Antarctic continent had strengthened as a result of complex interplay between modes of climate variability, including positive SAM, and synoptic-scale changes, such as increased density of short-term low-pressure systems. Spatial variability dominates all the processes at play, driving the overall circum-polar mean in sea-ice concentration and extent. 
For example, the regional combination of strengthened zonal winds with intensification of centres of cyclolysis resulted in the sea-ice edge relaxing northward of the long-term mean. Regional responses to both climate and synoptic-scale forcing varied considerably. Together they shaped a new historic record in maximum sea-ice extent late in September 2012, which since has been superseded in 2013 and 2014 [Reid et al., 2015], while in 2015 the overall maximum Antarctic sea-ice extent was close to the observed long-term average. The SIPEX 2012 sea-ice region was characterised by a short summer with little open water in early 2012. In this region, as well as in the western Ross Sea, SSTs were cooler than usual and the northward expansion of sea ice started early in autumn, indicating pre-conditioning of the regional sea ice in 2012 by events from the previous season.

Sea-ice characteristics in the same region were quite different between years, e.g., for SIPEX 2007 compared to SIPEX 2012. During SIPEX 2007, the region was characterised by a negative ice-edge anomaly and relatively low sea-ice concentration [Stammerjohn et al., 2011], compared to positive ice-extent anomalies associated with a marked cold pool of surface waters in 2012. During SIPEX 2012, distinct zonal structuring occurred in the sea-ice zone due to stronger than normal southerlies in the north (pushing the ice extent to the north) but stronger than normal northerlies in the southern zone (likely acting to compact the sea ice). Heavily deformed sea ice appeared to be associated with increased cyclonicity coupled with a regionally intensified westward ice flow and a localised high-strain region associated with two large icebergs constricting ice drift across the western side of the SIPEX 2012 region. At the same time, enhanced influx of ice from the east resulted from a reshaping of the coastal "icescape" upstream following the calving of the Mertz Glacier Tongue in 2010. This led to a broader westward flowing stream of sea ice within the coastal current, possibly supplemented by westward propagation of sea ice from a positive anomaly in ice extent originating in the western Ross Sea in 2012. No such anomaly has been identified during 2006 - 2008, i.e. during SIPEX 2007. This indicates that the extreme sea-ice characteristics encountered during SIPEX 2012 were the result of a number of compounding conditions rather than a single driver, suggesting that these kinds of extreme sea-ice conditions may be transient rather than an indication of long-term change.

\section{Acknowledgements}

GSFC SMMR-SSM/I sea-ice concentration data were acquired from the EOS Distributed Active Archive Center at the National Snow and Ice Data Center, USA. Daily sea-ice motion data were obtained from the US National Snow and Ice Data Center, USA (http://nsidc.org/data/docs/daac/nsidc0116_icemotion.gd.html). MODIS imagery were obtained from NASA's MODIS archive (http://ladsweb.nascom.nasa.gov/). Precipitation data were derived from the European Centre for Medium range Weather Forecasts (ECMWF) Interim Reanalysis dataset (http://www.ecmwf.int/research/era/do/get/era-interim). National Center for Environmental Prediction [NCEP]-2 reanalysis data are from the NOAA/OAR/ESRL PSD, Boulder, Colorado, USA (http://www.cdc.noaa.gov/). NOAA's Earth Systems Research Laboratory provided the SST data, updated from Reynolds et al. [2002], (http://www.esrl.noaa.gov/psd/data/gridded/data.noaa.oisst.v2.html). The SAM index was based on Marshall [2003] (http://www.nerc-bas.ac.uk/icd/gjma/sam.html). Bathymetry data are from GEBCO (http://www.bodc.ac.uk/data/online_delivery/gebco/). Brigham Young University [USA] are thanked for their Antarctic Iceberg Tracking Database obtained from the NASA sponsored Scatterometer 
Climate Record Pathfinder, courtesy of D.G. Long

[http://www.scp.byu.edu/data/iceberg/database1.html].

We thank the chief scientist K. Meiners, voyage management and crew of the RSV Aurora Australis for their support during SIPEX 2012. Cyclone statistics were generously provided by K. Keay (prev. University of Melbourne), and his help is highly appreciated. G. Hyland (AAD and $A C E$ CRC) is thanked for developing an analysis tool to process the passive microwave sea-ice velocity data set.

This work was supported by the Australian Government's Cooperative Research Centres Programme through the Antarctic Climate and Ecosystems Cooperative Research Centre. The International Space Science Institute (Bern, Switzerland) is thanked for supporting scientific collaborations of this study through project "Space-borne monitoring of polar sea ice" (\#169). JKH's SIPEX 2012 involvement was funded by the National Science Foundation's Office of Polar Programs grant 1023662.

This work contributes to the Australian Antarctic Science projects 4072, 4073, 4116, and 4301 and the World Climate Research Programme's CliC activity Linkages Between Cryosphere Elements.

\section{References}

Bintanja R., G.J. van Oldenborgh, S.S. Drijfhout, B. Wouters, and C.A. Katsman, Important role for ocean warming and increased ice-shelf melt in Antarctic sea-ice expansion, Nat. Geosc., 6(4), 1 - 4, doi:10.1038/ngeo1767, 2013.

Bintanja, R., G.J. Van Oldenborgh, and C.A. Katsman, The effect of increased fresh water from Antarctic ice shelves on future trends in Antarctic sea ice, Ann. Glaciol., 69, doi:10.3189/2015AoG69001, 2015.

Comiso, J.C., Bootstrap sea ice concentrations from NIMBUS-7 SMMR and DMSP SSM/I 1979-2012, National Snow and Ice Data Center, Boulder, USA, Digital media, 1999.

Eicken, H., M.A. Lange, H.-W. Hubberton, and P. Wadhams, Characteristics and distribution patterns of snow and meteoric ice in the Weddell Sea and their contribution to the mass balance of sea ice, Ann. Geophys., 12 (1), 80 - 93, 1994.

Fowler, C., Polar Pathfinder Daily 25 km EASE-Grid Sea Ice Motion Vectors, 1979 - 2012, National Snow and Ice Data Center, Boulder, USA, Digital media, 2003.

Gloersen P., W.J. Campbell, D.J. Cavalieri, J.C. Comiso, C.L. Parkinson, and H.J. Zwally, Arctic and Antarctic Sea Ice, 1978 - 1987: Satellite Passive Microwave Observations and Analysis. NASA Special Publication, 511, 1992.

Hande, L.B., S.T. Siems, and M.J. Manton, Observed trends in wind speed over the Southern Ocean, Geophys. Res. Lett., 39, L11802, doi:10.1029/2012GL051734, 2012.

Heil, P., Atmospheric conditions and fast ice at Davis, East Antarctica: A case study, J. Geophys. Res., 111(C5), C05010, doi:10.1029/2005JC002904, 2006. 
Heil, P., and I. Allison, The pattern and variability of Antarctic sea-ice drift in the Indian Ocean and western Pacific sectors, J. Geophys. Res., 104 (C7), 15789 - 15802, 1999.

Heil, P., J.K. Hutchings and others, Sea-ice kinematics off East Antarctica in extreme ice conditions, in prep.

Heil, P., R.A. Massom, I. Allison, and A.P. Worby, Physical attributes of sea-ice kinematics during spring 2007 off East Antarctica, Deep-Sea Res. II.,58, 1158 - 1171, doi:10.1016/j.dsr2.2010.12.004, 2011.

Holland, P.R., The seasonality of Antarctic sea ice trends, Geophys. Res. Lett., 41, 42304237, doi:10.1002/2014GL060172, 2014.

Holland P.R., and R. Kwok, Wind-driven trends in Antarctic sea-ice drift, Nat. Geosc., 5(12), 872 - 875, doi:10.1038/ngeo1627, 2012.

Hutchings, J.K., P. Heil, O. Lecomte, R. Stevens, A. Steer, and J.L. Lieser, Comparing methods of measuring sea ice density in the East Antarctic, Ann. Glaciol., 69, doi:10.3189/2015AoG69A814, 2015.

Jones, D.A., and I. Simmonds, A climatology of Southern Hemisphere extratropical cyclones, Clim. Dynamics, 9, 131 - 145, 1993.

Kern, S., and G. Spreen, Uncertainties in Antarctic sea-ice thickness retrieval from ICESat, Ann. Glaciol., 56(69), 107 - 119, doi:10.3189/2015AoG69A736, 2015.

Kohout, A.L., M.J.M. Williams, S.M. Dean, and M.H. Meylan, Storm-induced sea-ice breakup and the implications for ice extent, Nature, 509, $804-807$, doi:10.1038/nature13262, 2014.

Kriegsmann, A., and B. Bruemmer, Cyclone impact on sea ice in the central Arctic Ocean: A statistical study, The Cryosphere, 8, 303 - 317, doi:10.5194/tc-8-303-2014, 2014.

Kwok R., Near zero replenishment of the Arctic multiyear sea ice cover at the end of 2005 summer, Geophys. Res. Lett., 34, L05501, doi:10.1029/2006GL028737, 2007.

Lannuzel, D., F. Chever, P.C. van der Merwe, J. Janssens, A. Roukaerts, A.-J. Cavagna, A.T. Townsend, A.R. Bowie and K.M. Meiners, Iron biogeochemistry in Antarctic pack ice during SIPEX-2, Deep-Sea Res. II, doi:10.1016/j.dsr2.2014.12.003, 2016.

Lindsay, R. and A. Schweiger, Arctic sea ice thickness loss determined using subsurface, aircraft, and satellite observations, The Cryosphere, 9, 269 - 283, doi:10.5194/tc-9-269-2015, 2015.

Liu J., and J.A. Curry, Accelerated warming of the Southern Ocean and its impacts on the hydrological cycle and sea ice, Proc. Nat. Ac. Sc., 107(34), 1987 - 1992, 
doi:10.1073/pnas.1003336107, 2010.

Lubin, D., and R.A. Massom, Polar Remote Sensing 1: Atmosphere and Polar Oceans, Praxis/Springer, Chichester, UK and Berlin, Germany, 756pp, 2006.

Maksym, T., and T. Markus, Antarctic sea ice thickness and snow-to-ice conversion from atmospheric reanalysis and passive microwave snow depth J. Geophys. Res., 113(C2): C02S12, doi:10.1029/2006JC004085, 2008.

Maksym, T., S.E. Stammerjohn, S. Ackley, and R. Massom, Antarctic sea ice - A polar opposite? Oceanogr., 25(3),140 - 151, doi:10.5670/oceanog.2012.88, 2012.

Marshall, G.J., Trends in the Southern Annular Mode from observations and reanalyses, J. Clim., 16, $4134-4143,2003$.

Maslanik, J., J. Stroeve, C. Fowler, and W. Emery, Distribution and trends in Arctic sea ice age through spring 2011, Geophys. Res. Lett., 38, L13502, doi:10.1029/2011GL047735, 2011.

Massom, R.A., and S.E. Stammerjohn, Antarctic sea ice change and variability - Physical and ecological implications, Polar Sc., 4, 149 - 186, 2010.

Massom, R.A., H. Eicken, C. Haas, M.O. Jeffries, M.R. Drinkwater, M. Sturm, A.P. Worby, X. Wu, V.I. Lytle, S. Ushio, K. Morris, P.A. Reid, S.G. Warren and I. Allison, Snow on Antarctic sea ice, Rev. Geophys., 39 (3), $413-445,2001$.

Massom, R.A., P. Reid, S. Stammerjohn, S. Barreira, J. Lieser, and T.A. Scambos, Sea-ice extent and concentration, in State of the Climate in 2012, Bull. Am. Meteor. Soc., 94 (8), S141 - S142, 2013a.

Massom R., P. Reid, S. Stammerjohn, B. Raymond, A. Fraser, and S. Ushio, Change and variability in East Antarctic sea ice seasonality, 1979/80-2009/10, PloS ONE, 8(5), e64756. doi:10.1371/journal.pone.0064756, 2013b.

Massom, R.A., A. Worby, V. Lytle, T. Markus, I. Allison, T. Scambox, H. Enomoto, K. Tateyama, T. Haran, J.C. Comiso, A. Pfaffling, T. Tamura, A. Muto, P. Kanagaratnam, B. Giles, N. Young, G. Hyland, and E. Key, ARISE (Antarctic Remote Ice Sensing Experiment) in the East 2003: Validation of satellite-derived sea-ice data products, Ann. Glaciol., 44, 288 296, 2006.

Meiners, K.M., K. Golden, P. Heil, J.L. Lieser, R. Massom, B. Meyer and G.D. Williams, Introduction: SIPEX-2, a study of sea ice physical, biogeochemical and ecosystem processes off East Antarctica during spring 2012, Deep-Sea Res. II, doi:10.1016/j.dsr2.2016.06.010, 2016.

Murray, R.J., and I. Simmonds, A numerical scheme for tracking cyclone centres from digital data. Part I: Development and operation of the scheme, Austral. Meteorol. Mag., 39, 155 - 
166, 1991.

NASA, Arctic Sea Ice Minimum, http://climate.nasa.gov/vital-signs/arctic-sea-ice/, 2016.

NSIDC, Arctic sea ice reaches minimum extent for 2014, 22.09.2014, http://nsicc.org/arcticseaicenews/, 2014.

Overland, J.E., J.A. Francis, E. Hanna, and M. Wang, The recent shift in early summer Arctic atmospheric circulation, Geophys. Res. Lett., 39(19), doi:10.1029/2012GL053268, 2012.

Ozsoy-Cicek, B., S. Kern, S. F. Ackley, H. Xie, and A. E. Tekeli, Intercomparisons of Antarctic sea ice types from visual ship, RADARSAT-1 SAR, Envisat ASAR, QuikSCAT, and AMSR-E satellite observations in the Bellingshausen Sea, Deep-Sea Res. II, 58(9-10),1092 - 1111, doi:10.1016/j.dsr2.2010.10.031, 2011.

Perovich, D.K., The changing Arctic sea ice cover, Oceanography, 24(3), 162 - 173, doi:10.5670/oceanog.2011.68, 2011.

Pritchard H.D., S.R.M. Ligtenberg, H.A. Fricker, D.G. Vaughan, M.R. Van den Broeke, and L. Padman, Antarctic ice-sheet loss driven by basal melting of ice shelves, Nature, 484(7395), 502-505, doi:10.1038/nature10968, 2012.

Rampal, P., J. Weiss, and D. Marsan, Positive trend in the mean speed and deformation rate of Arctic sea ice: 1979-2007, J. Geophys. Res., 114, C05013, doi:10.1029/2008JC005066, 2009.

Reid P. and R.A. Massom, Successive Antarctic sea ice extent records during 2012, 2013 and 2014, In: State of the Climate in 2014, Special Suppl. to Bull. Am. Met. Soc., 96(7), S163S164, 2015.

Reid, P., S. Stammerjohn, R. Massom, T. Scambos, and J. Lieser, The record 2013 Southern Hemisphere sea-ice extent maximum, Ann.Glaciol., 56(69), 99 - 106, doi:10.3189/2015AoG69A892, 2015.

Reynolds, R.W., N.A. Rayner, T.M. Smith, D.C. Stokes, and W. Wang, An improved in situ and satellite SST analysis for climate, J. Clim., 15, 1609 - 1625, 2002.

Schmaltz, J., Collision calves iceberg from Mertz Glacier Tongue, Antarctica, Earth Observatory, NASA/GSFC, http://earthobservatory.nasa.gov/IOTD/view.php?id=42819, 2010. (Accessed: 20. August 2010).

Simmonds, I., Modes of atmospheric variability over the Southern Ocean., J. Geophys. Res., 108. doi:10.1029/2000JC000542, 2003.

Simmonds, I., and K. Keay, Mean Southern Hemisphere extra-tropical cyclone behavior in the 40-Year NCEP-NCAR reanalysis, J. Clim., 13, 873-885, 2000. 
Stammerjohn, S.E., D.G. Martinson, R.C. Smith, X. Yuan, and D. Rind, Trends in Antarctic annual sea ice retreat and advance and their relation to ENSO and Southern Annular Mode variability, J. Geophys. Res., 113, doi:10.1029/2007JC004269, 2008.

Stammerjohn, S., T. Maksym, P. Heil, R.A. Massom, M. Vancoppenolle, and K.C. Leonard, The influence of winds, sea-surface temperature and precipitation anomalies on Antarctic regional sea-ice conditions during IPY 2007, Deep-Sea Res. II, 58, 999 - 1018, doi:10.1016/j.dsr2.2010.10.026, 2011.

Stammerjohn, S., R. Massom, D. Rind, and D. Martinson, Regions of rapid sea ice change: An inter-hemispheric seasonal comparison, Geophys. Res. Lett., 39, L06501, doi:10.1029/2012GL050874, 2012.

Stuart, K.M., and D.G. Long, Tracking large tabular icebergs using the SeaWinds Ku-band microwave scatterometer, Deep-Sea Res. II, 58, 1285-1300, doi:10.1016/j.dsr2.2010.11.004, 2011.

Swart, N.C., and J.C. Fyfe, Observed and simulated changes in the Southern Hemisphere surface westerly wind-stress, Geophys. Res. Lett.2, 39, L16711 doi:10.1029/2012GL052810, 2012.

Taylor, P.C., M. Cai, A. Hu, J. Meehl, W. Washington, and G.J. Zhang, A decomposition of feedback contributions to polar warming amplification, Climate, 23(18), doi:10.1175/jcli-D-12$00696.1,2013$.

Toyota, T. R. Massom, O. Lecomte, D. Nomura, P. Heil, T. Tamura, and A.D. Fraser, On the extraordinary snow on the sea ice off East Antarctica in late winter, 2012, Deep-Sea Res. II, doi:10.1016/j.dsr2.2016.02.003, 2016.

Turner, J., J.S. Hosking, T.J. Bracegirdle, G.J. Marshall, and T. Phillips, Recent changes in Antarctic sea ice, Phil. Trans. R. Soc. A, 373, 1-13, 2015.

Uotila, P., T. Vihma, and M. Tsukernik, Close interactions between the Antarctic cyclone budget and large-scale atmospheric circulation, Geophys. Res. Lett, 40, doi:10.1002/grl.50560, 2013.

Williams, G.D., T. Maksym, J. Wilkinson, C. Kunz, C. Murphy, P. Kimball, and H. Singh, Thick and deformed Antarctic sea ice mapped with autonomous underwater vehicles, Nat. Geosc., 8, 61 - 67, doi:10.1038/ngeo2299, 2015.

Worby, A. P. and I. Allison, A technique for making ship-based observations of Antarctic sea ice thickness and characteristics, Part I: Observational technique and results, Antarctic CRC Research Report, 14, 1 - 23, 1999.

Worby A.P., C.A. Geiger, M.J. Paget, M.L. Van Woert, and S.F. Ackley, Thickness distribution 
of Antarctic sea ice, J. Geophys. Res., 113, C05S92, doi:10.1029/20, 2008.

Worby A.P., R.A. Massom, I. Allison, V.I. Lytle, and P. Heil, East Antarctic sea ice: A review of its structure, properties and drift, Ant. Res. Ser., 74, 41 - 67, 1998.

Worby, A.P., A. Steer, J.L. Lieser, P. Heil, D. Yi, T. Markus, I. Allison, R.A. Massom, N. Galin, and $\mathrm{J}$. Zwally, Regional-scale sea-ice and snow thickness distributions from in situ and satellite measurements over East Antarctica during SIPEX 2007, Deep-Sea Res. II, 58(910),1125 - 1136, doi:10.1016/j.dsr2.2010.12.001, 2011.

Wovrosh, A.J., S. Barreira, R.L. Fogt, and T.A. Scambos, Circulation, In: State of the Climate in 2012, Bull. Am. Meteor. Soc., 94 (8), S133 - S135, 2013.

Wu, X., W.F. Budd, V.I. Lytle and R.A. Massom, The effect of snow on Antarctic sea-ice simulations in a coupled atmosphere sea-ice model, Climate Dyn., 15, 127 - 143, 1999.

Xie, H., A.E. Tekeli, S.F. Ackley, D. Yi, and H.J. Zwally, Sea ice thickness estimations from ICESat altimetry over the Bellingshausen and Amundsen seas, 2003 - 2009, J. Geophys. Res., 118, 2438 - 2453, doi:10.1002/jgrc.20179, 2013.

Yang, X.-Y., R.X. Huang, and D.X. Wang, Decadal changes of wind stress over the Southern Ocean associated with Antarctic ozone depletion, J. Clim., 20, doi:10.1175/JCLI4195.1, 2007.

Zhang, X.-Y., R.X. Huang, and D.X. Wang, Decadal changes of wind stress over the Southern Ocean associated with Antarctic ozone depletion, J. Clim., 20(14), 3395 - 3410, 2007.

Zwally, H.J., D. Yi, R. Kwok, and Y. Zhao, ICESat measurements of freeboard and estimates of sea-ice thickness in the Weddell Sea, J. Geophsys. Res., 113, C02S15, doi:10.1029/2007/JC04284, 2008. 


\section{Table and figure captions}

Tab.1: Regional sea-ice trends within $63^{\circ}-67^{\circ} \mathrm{S} / 115^{\circ}-130^{\circ} \mathrm{E}$ for 1979 to 2012.

Fig 1: a) The SIPEX 2012 trajectory shows daily progress (dots), where blue dots indicating restricted freedom of

movement by the vessel and yellow dots showing when the vessel was beset. The trajectory of B09D is shown in grey

with daily positions marked with cyan dots. Red lines show the distance between the vessel and B09D at 3 occasions.

Bathymetric contours are also shown in in this panel. MODIS visible images showing the ice state on b) 04.10 .2012 and

c) 06.11.2012. Grey dashed lines depict shear lines within the ice pack. The vessel's positions on 04.10.2012 (purple

star) and 06.11.2012 (orange star) are shown in a).

Fig. 2: April - November 2012 (a-h) monthly means of SMMR-SSM/I sea-ice concentration and NNR monthly winds for the East Antarctic Region $\left(90^{\circ}\right.$ to $\left.150^{\circ} \mathrm{E}\right)$. The red box outlines the research area $\left(117^{\circ}\right.$ to $\left.121^{\circ} \mathrm{E}\right)$. Solid contours indicate the monthly $15 \%$ (black) and $75 \%$ (white) sea-ice concentration isopleths, while the dashed contours are the 1980-2012 mean locations of the $15 \%$ and $75 \%$ isopleths, respectively.

Fig. 3: Anomalies of (a) sea-ice advance, (b) retreat, and (c) sea-ice duration for 2012, as well as the (d) duration trend, all relative to 1979-2014 (see Stammerjohn et al. [2008]) using GSFC bootstrap V2 data [Comiso, 1999].

Fig. 4: Monthly (Jan - Dec 2012) anomalies in sea-surface temperature $\left[{ }^{\circ} \mathrm{C}\right]$ and sea-ice concentration [\%] and geopotential height [hPa] (black contours) off East Antarctica.

Fig. 5: April - November 2012 (a-h) mean monthly sea-ice velocity derived from SSM/I brightness temperatures for the region of interest within the East Antarctic sea-ice zone. For clarity only every 2 nd vector is shown.

Fig. 6: Normalised horizontal flux in a) East-West and b) North-South direction, derived from passive microwave ice motion and concentration data. Fluxes were calculated for flux gates at $135^{\circ} \mathrm{E}$ (blue) and $138^{\circ} \mathrm{E}$ (black).

Fig. 7: Daily mean sea-ice motion (coloured lines) from in situ ice buoys deployed during SIPEX 2012 is traced by daily-observed iceberg motion for B09-D (blue dots), which moved about $5-60 \mathrm{~km}$ to the south of the ice buoys. Monthly mean iceberg motion is also shown (red dots).

Fig. 8: Monthly (a) Jan - I) Dec 2012) anomalies of cyclone system density compared to the 1979 - 2015 mean derived from ECMWF reanalysis.

Fig. 9: Hovmoeller diagrams of sea-ice extent anomalies centered on SIPEX 2007 (a) and 
SIPEX 2012: Extreme sea-ice and atmospheric conditions off East Antarctica Table and Figures

Tab. 1: Regional sea-ice trends within $63^{\circ}-67^{\circ} \mathrm{S} / 115^{\circ}-130^{\circ} \mathrm{E}$ for 1979 to 2012.

\begin{tabular}{|l|c|c|c|}
\hline & Trend & SD & Probability \\
\hline Annual extent $\left(\mathrm{km}^{2} \mathrm{yr}^{-1}\right)$ & +727 & \pm 648 & $(p=0.14)$ \\
\hline Sea-ice advance $\left(\right.$ days $\left.\mathrm{yr}^{-1}\right)$ & -0.34 & \pm 0.26 & $(p=0.10)$ \\
\hline Sea-ice retreat $\left(\right.$ days $\left.\mathrm{yr}^{-1}\right)$ & +0.16 & \pm 0.12 & $(p=0.09)$ \\
\hline Ice duration (days $\left.\mathrm{yr}^{-1}\right)$ & +0.50 & \pm 0.30 & $(p=0.06)$ \\
\hline Open-water duration $\left(\right.$ days $\left.\mathrm{yr}^{-1}\right)$ & -0.57 & \pm 0.36 & $(p=0.07)$ \\
\hline
\end{tabular}




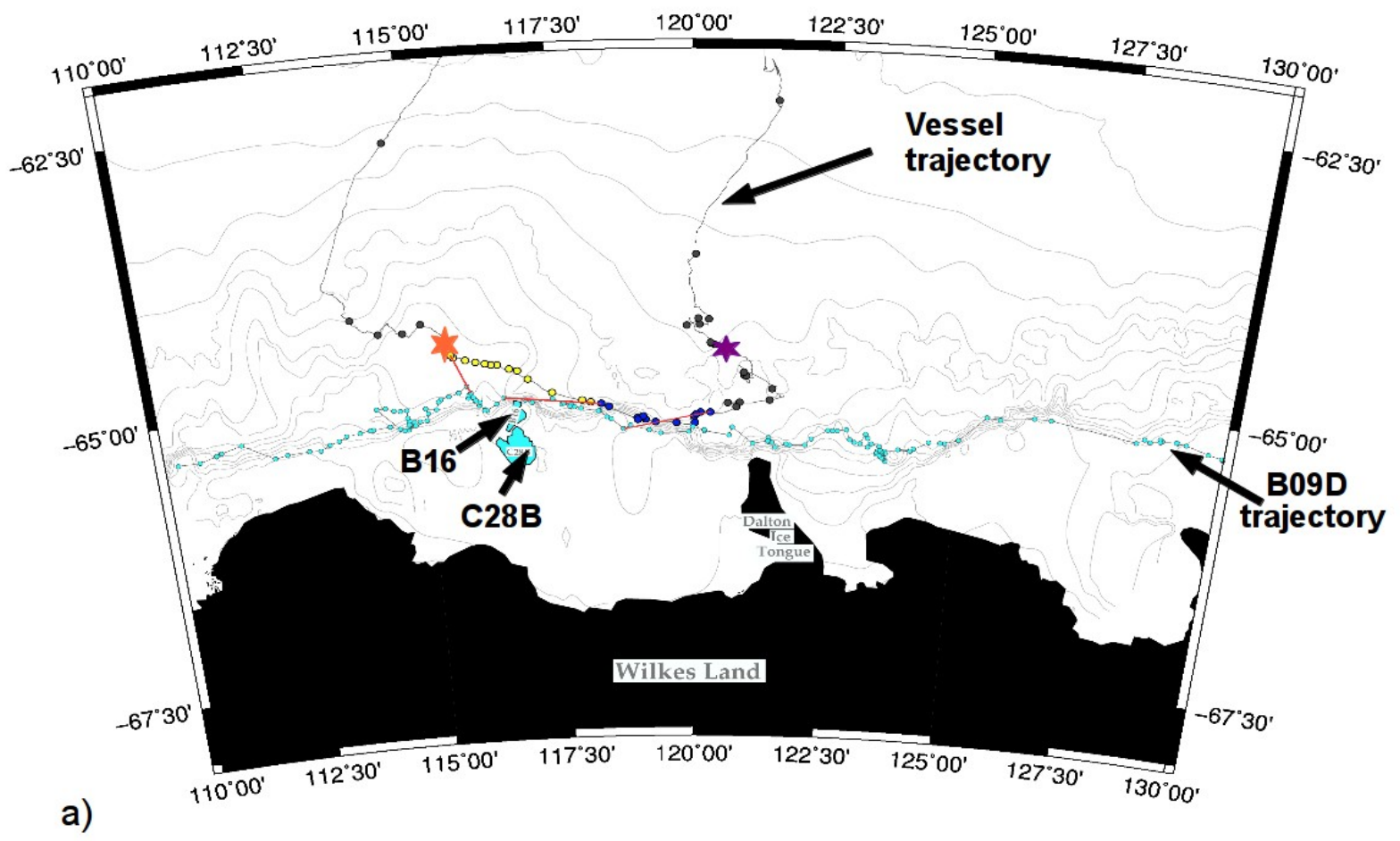

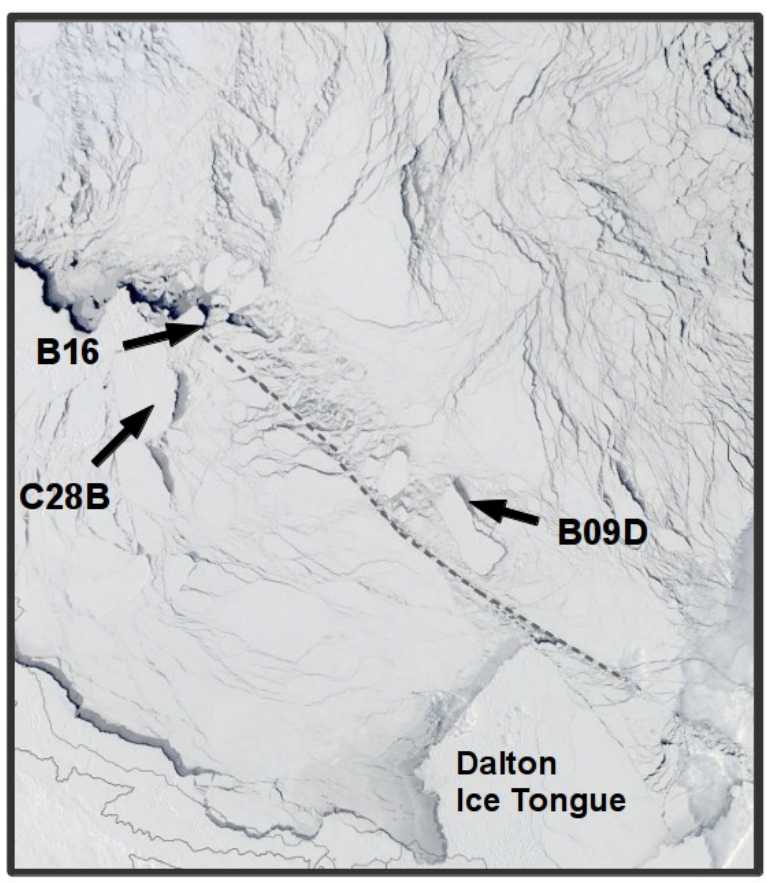

b)

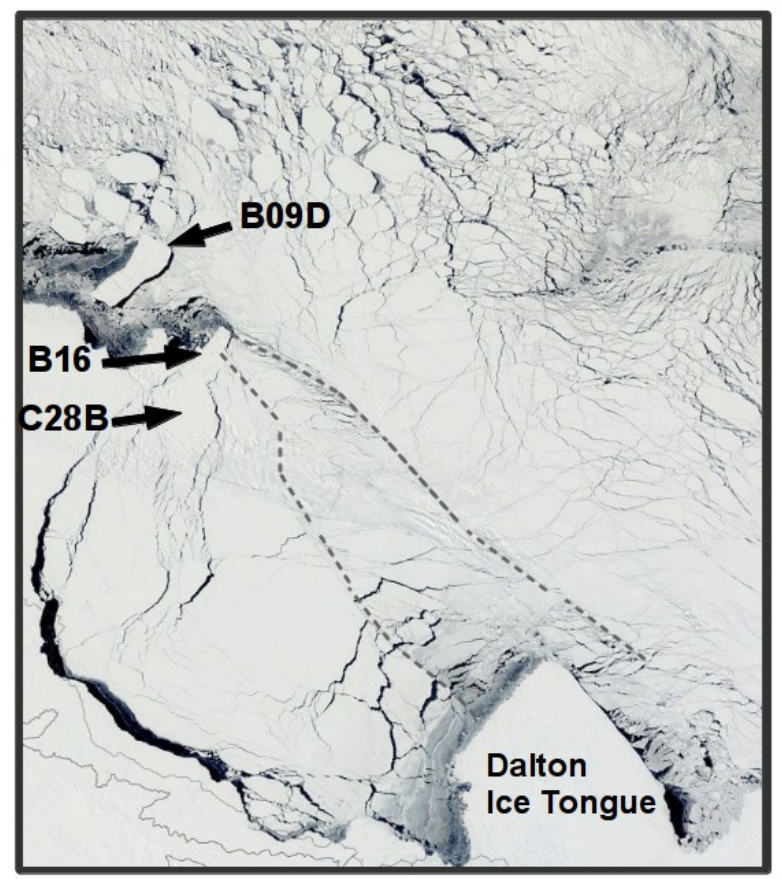

c)

06 Nov 2012

Fig 1: a) The SIPEX 2012 trajectory shows daily progress (dots), where blue dots indicating restricted freedom of movement by the vessel and yellow dots showing when the vessel was beset. The trajectory of BĐ09D is shown in grey with daily positions marked with cyan dots. Red lines show the distance between the vessel and BD09D at 3 occasions. Bathymetric contours are also shown in-in this panel. MODIS visible images showing the ice state on b) 04.10 .2012 and c) 06.11.2012. Grey dashed lines depict shear lines within the ice pack. The vessel's positions on 04.10.2012 (purple star) and 06.11.2012 (orange star) are shown in a). 
(a) Apr. 2012

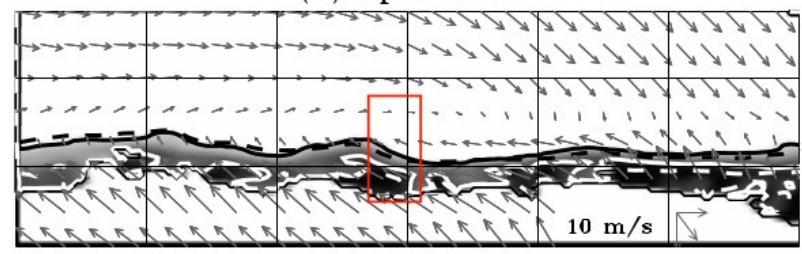

(c) Jun. 2012

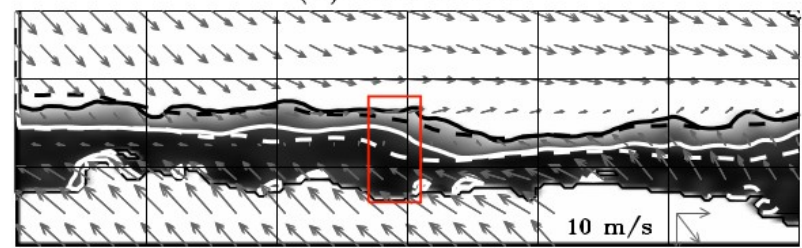

(e) Aug. 2012

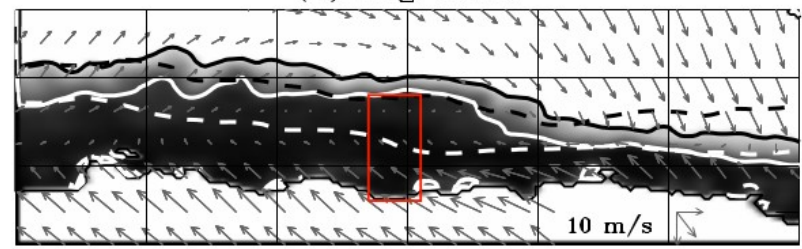

(g) Oct. 2012

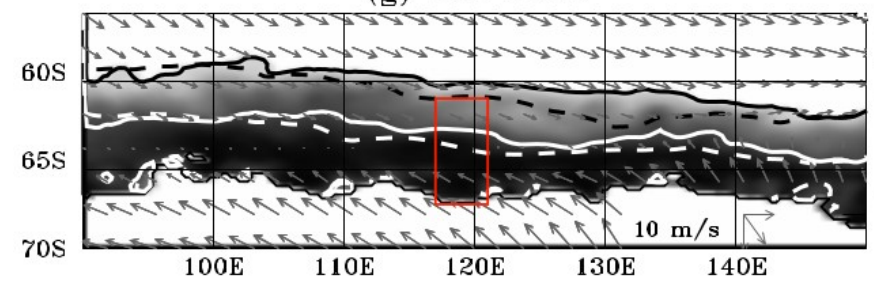

(b) May. 2012

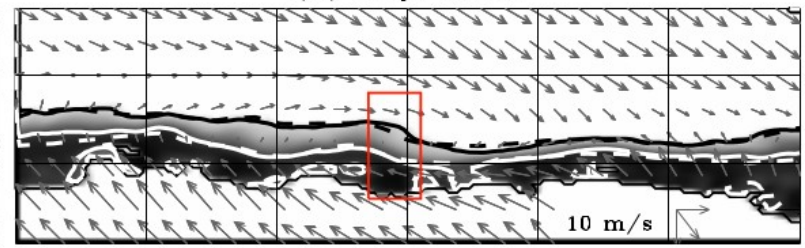

(d) Jul. 2012

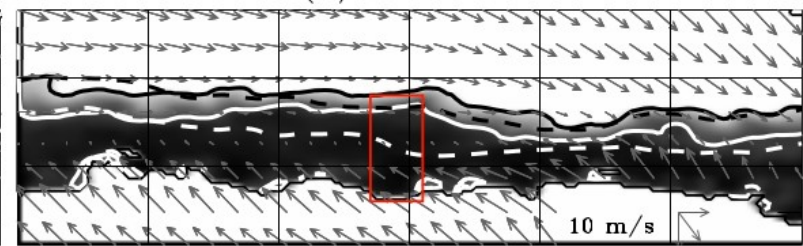

(f) Sep. 2012

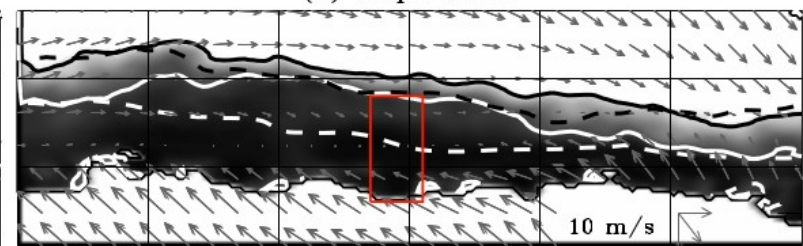

(h) Nov. 2012

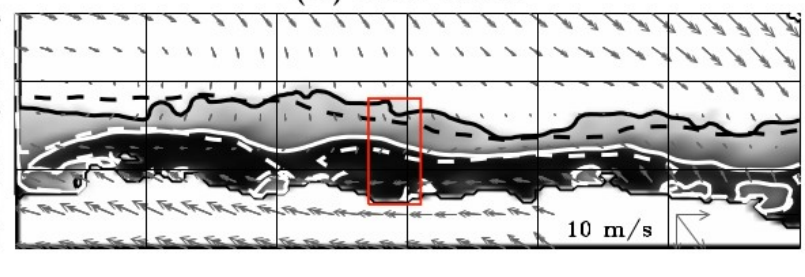

75

100

Ice Concentration, \%

Fig. 2: April - November 2012 (a-h) monthly means of SMMR-SSM/l sea-ice concentration and NNR monthly winds for the East Antarctic Region $\left(90^{\circ}\right.$ to $\left.150^{\circ} \mathrm{E}\right)$. The red box outlines the research area $\left(117^{\circ}\right.$ to $\left.121^{\circ} \mathrm{E}\right)$. Solid contours indicate the monthly $15 \%$ (black) and $75 \%$ (white) sea-ice concentration isopleths, while the dashed contours are the 1980-2012 mean locations of the $15 \%$ and $75 \%$ isopleths, respectively. 
(a) Advance

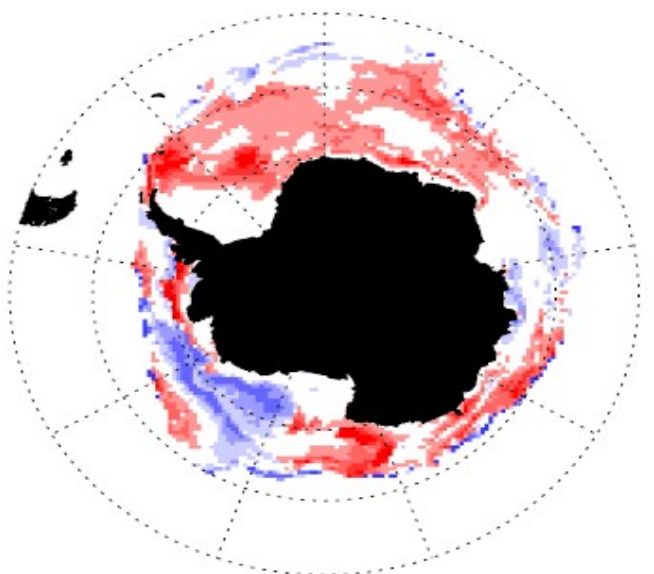

(b) Retreat

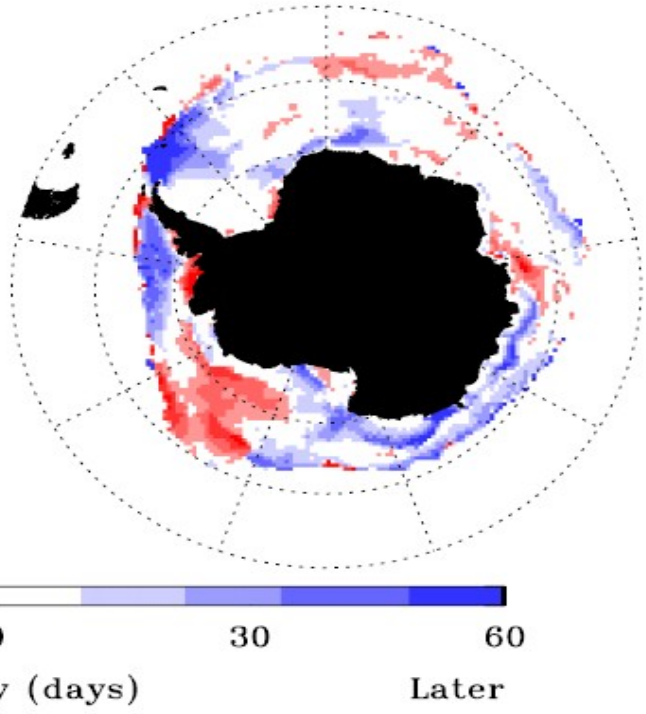

(d) Duration Trend

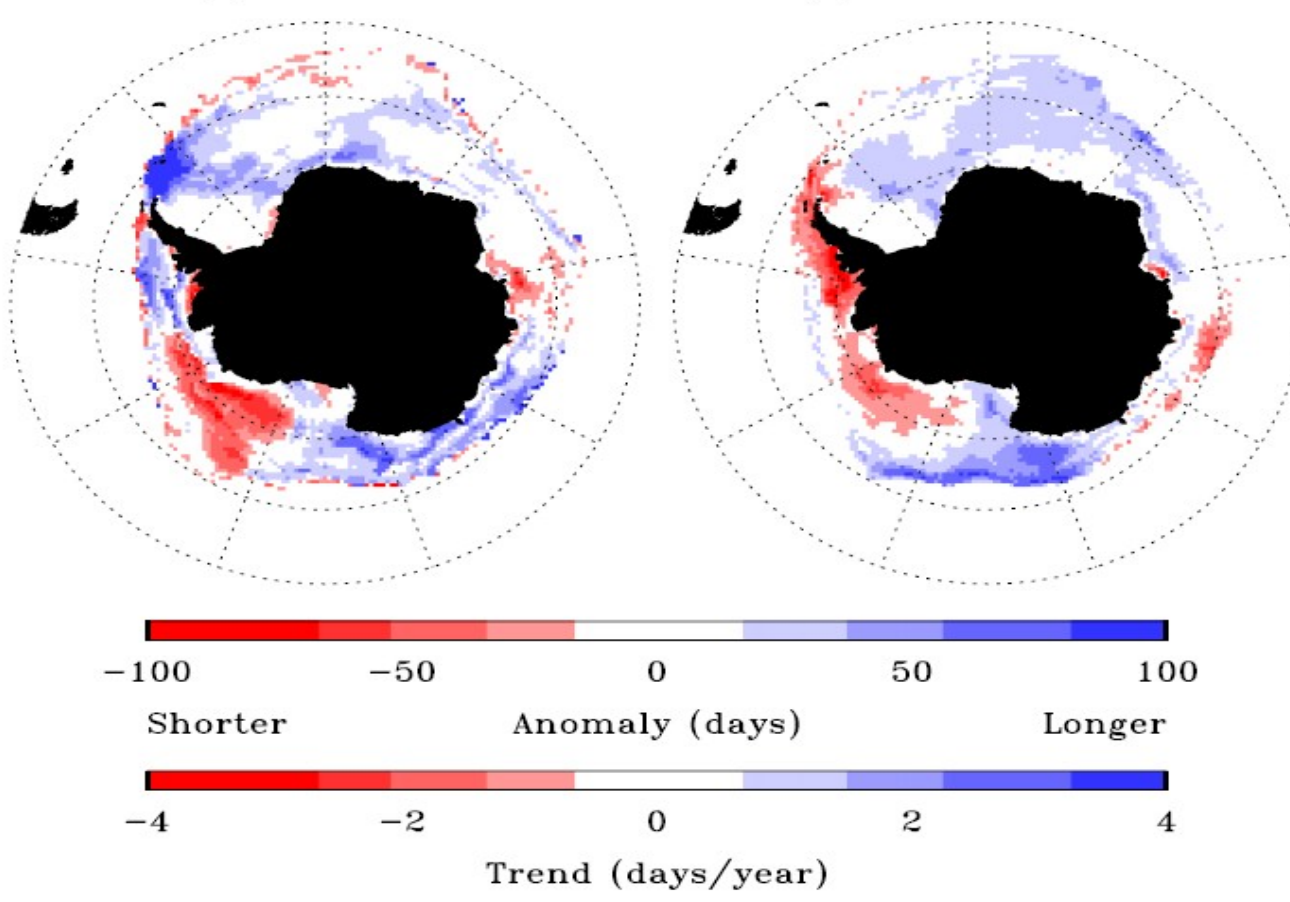

Fig. 3: Anomalies of (a) sea-ice advance, (b) retreat, and (c) sea-ice duration for 2012, as well as the (d) duration trend, all relative to 1979 - 2014 (see Stammerjohn et al._[2008]) using GSFC bootstrap V2 data [Comiso, 1999]. 

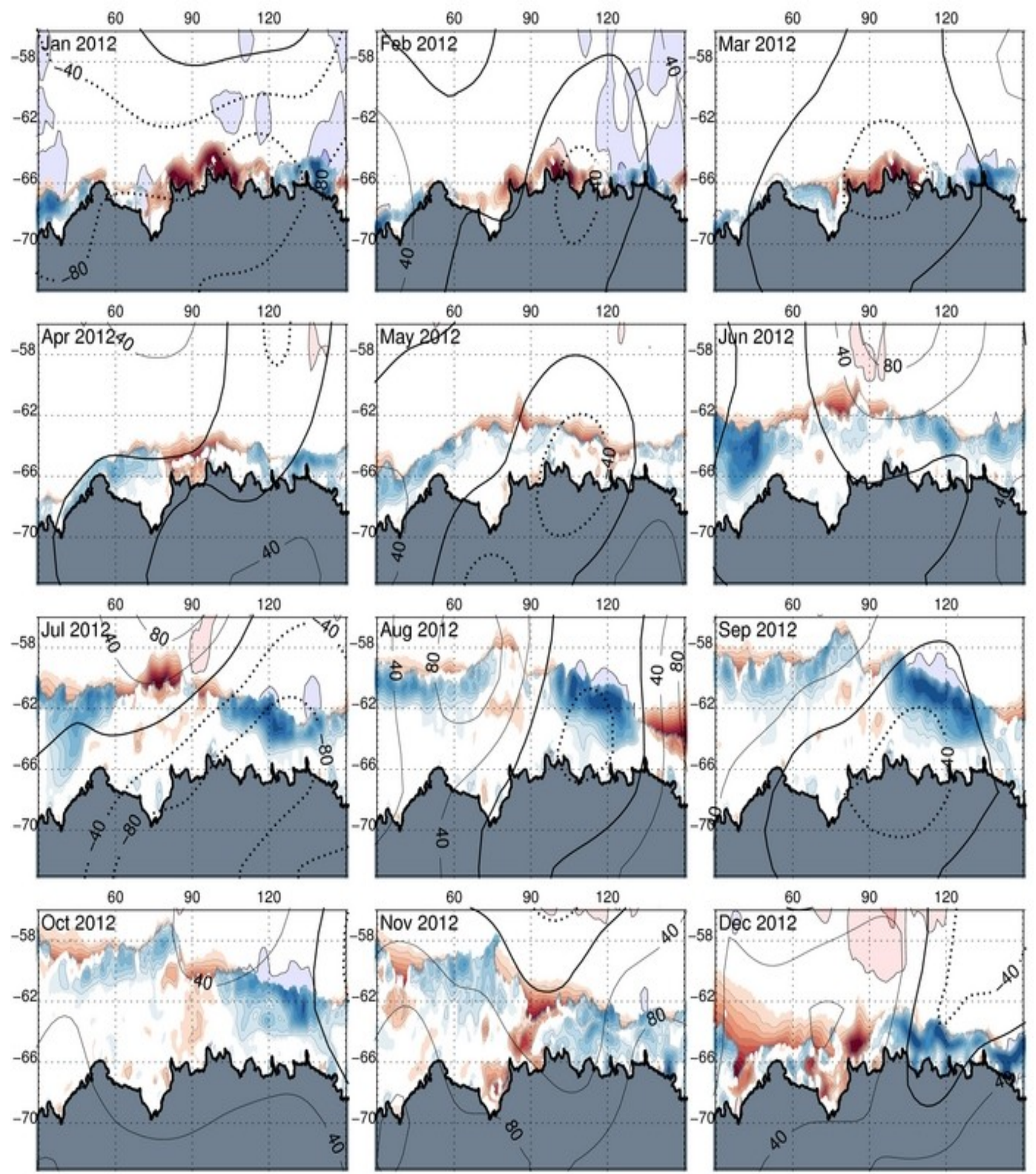

(\%)

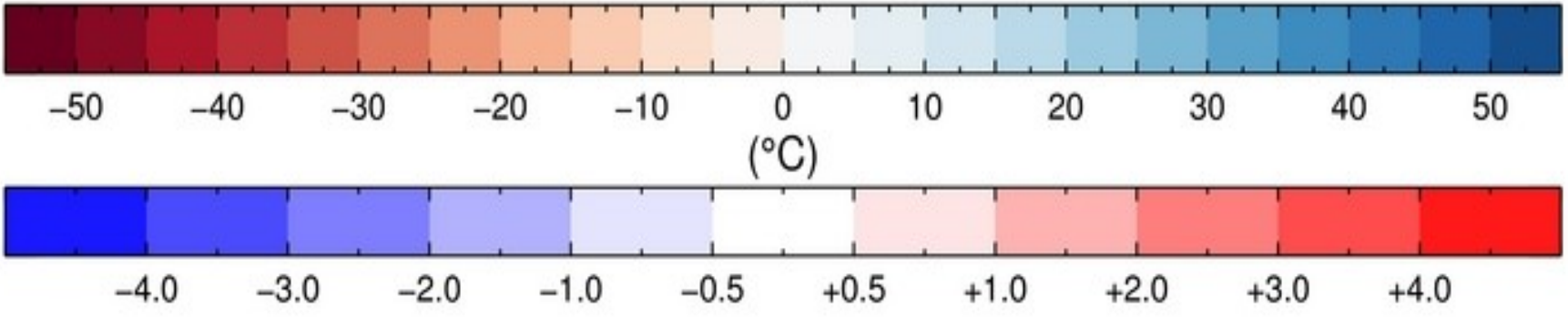

Fig. 4: Monthly (Jan - Dec 2012) anomalies in sea-surface temperature $\left[{ }^{\circ} \mathrm{C}\right]$ and sea-ice concentration [\%] and geopotential height [hPa] (black contours) off East Antarctica. 

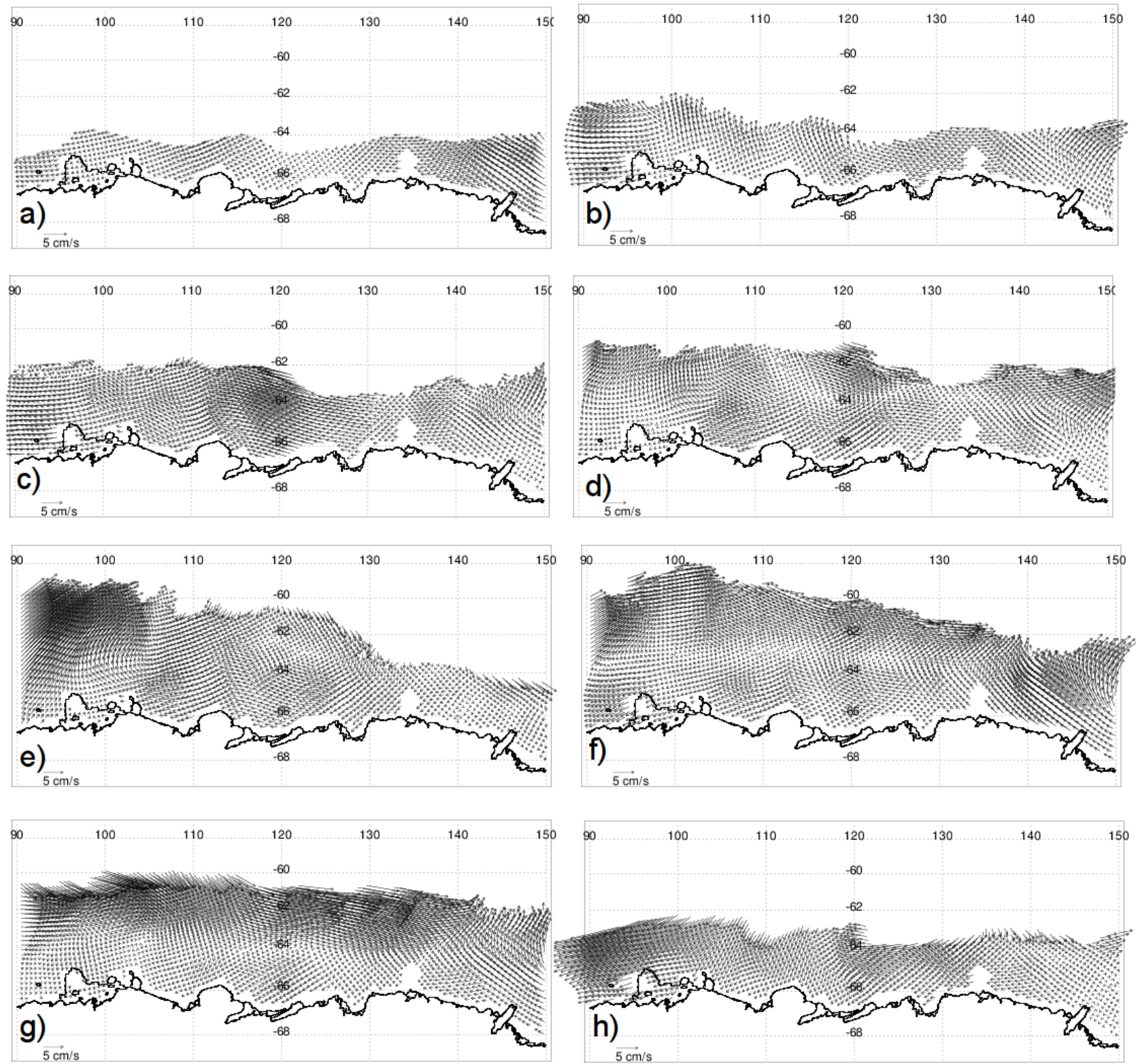

Fig. 5: April - November 2012 (a-h) mean monthly sea-ice velocity derived from SSM/I brightness temperatures for the region of interest within the East Antarctic sea-ice zone. For clarity only every 2nd vector is shown. 

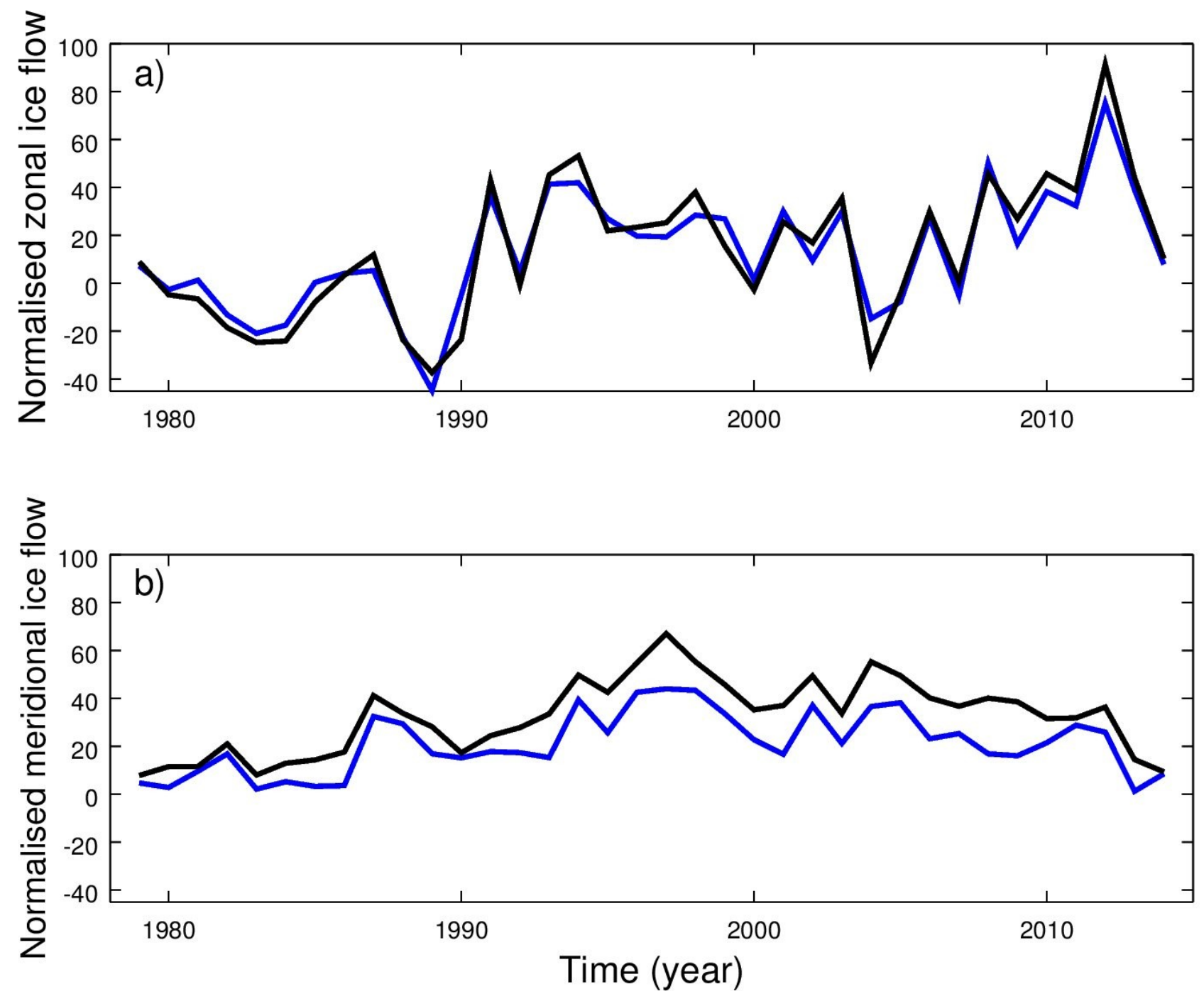

Fig. 6: Normaliszzed horizontal flux in a) East-West and b) North-South direction, derived from passive microwave ice motion and concentration data. Fluxes were calculated for flux gates at $135^{\circ} \mathrm{E}$ (blue) and $138^{\circ} \mathrm{E}$ (black). 


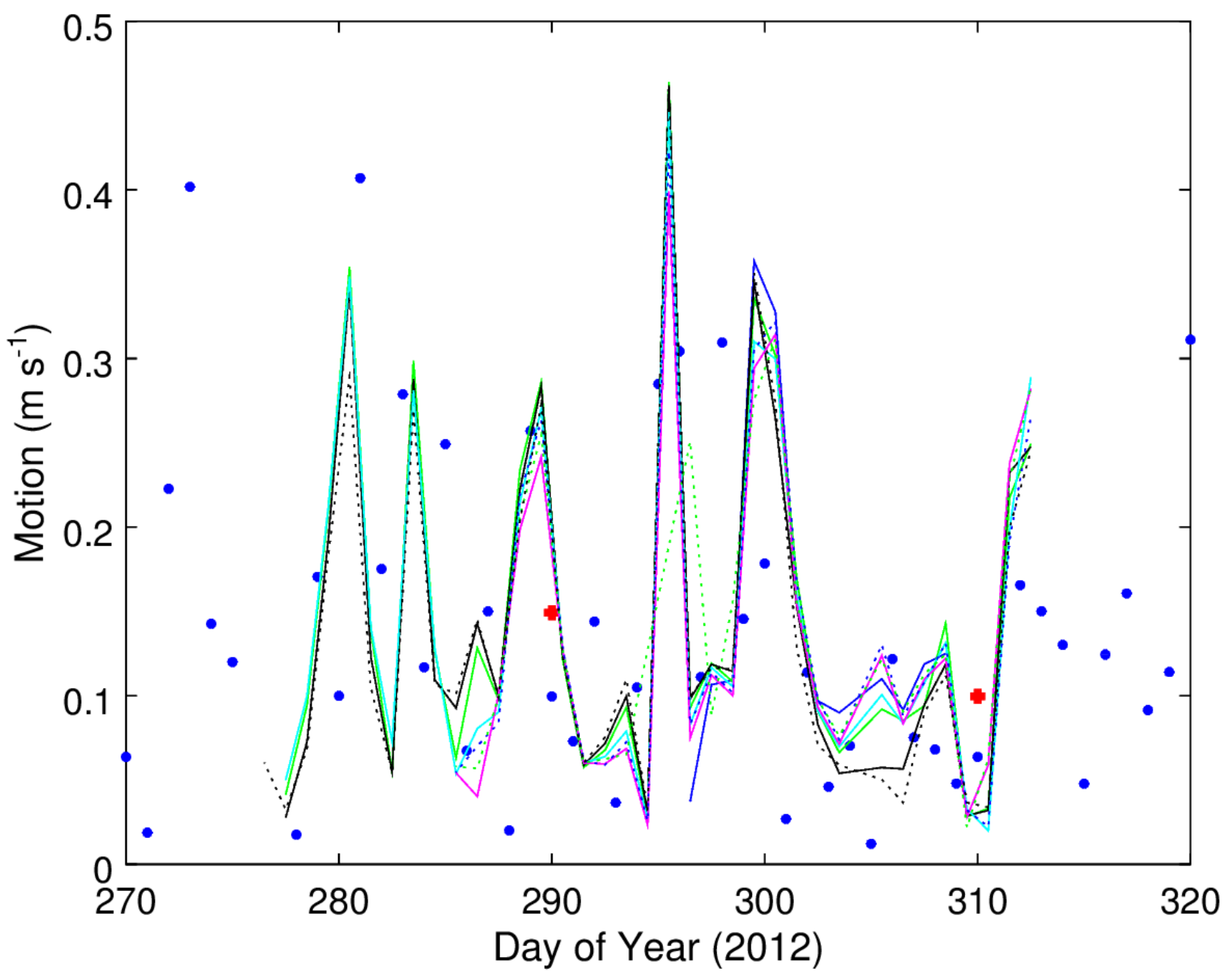

Fig. 7: Daily mean sea-ice motion (coloured lines) from in situ ice buoys deployed during SIPEX 2012 is traced by dailyobserved iceberg motion for B09-D (blue dots), which moved about $5-60 \mathrm{~km}$ to the south of the ice buoys. Monthly mean iceberg motion is also shown (red dots). 

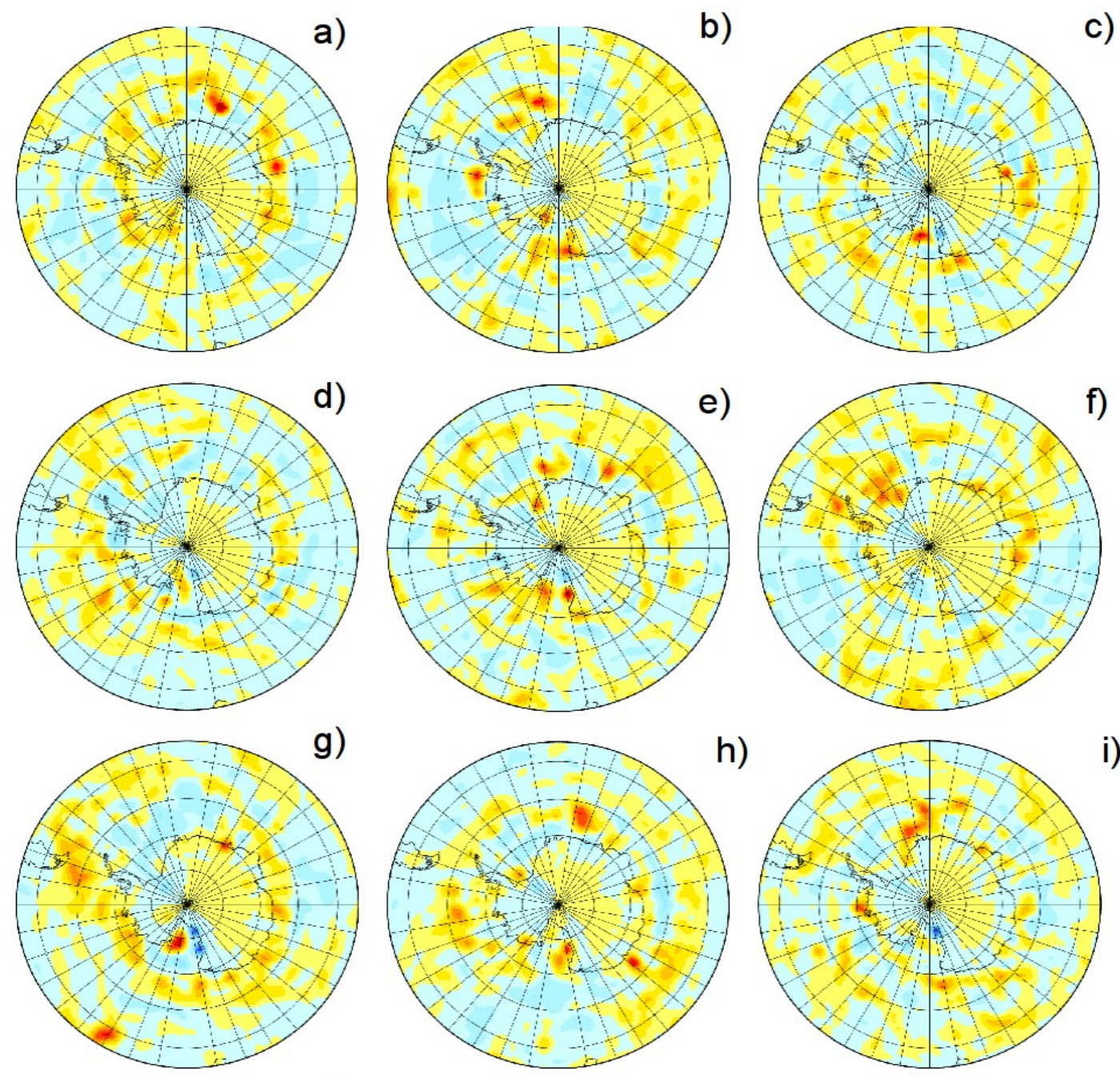

h)
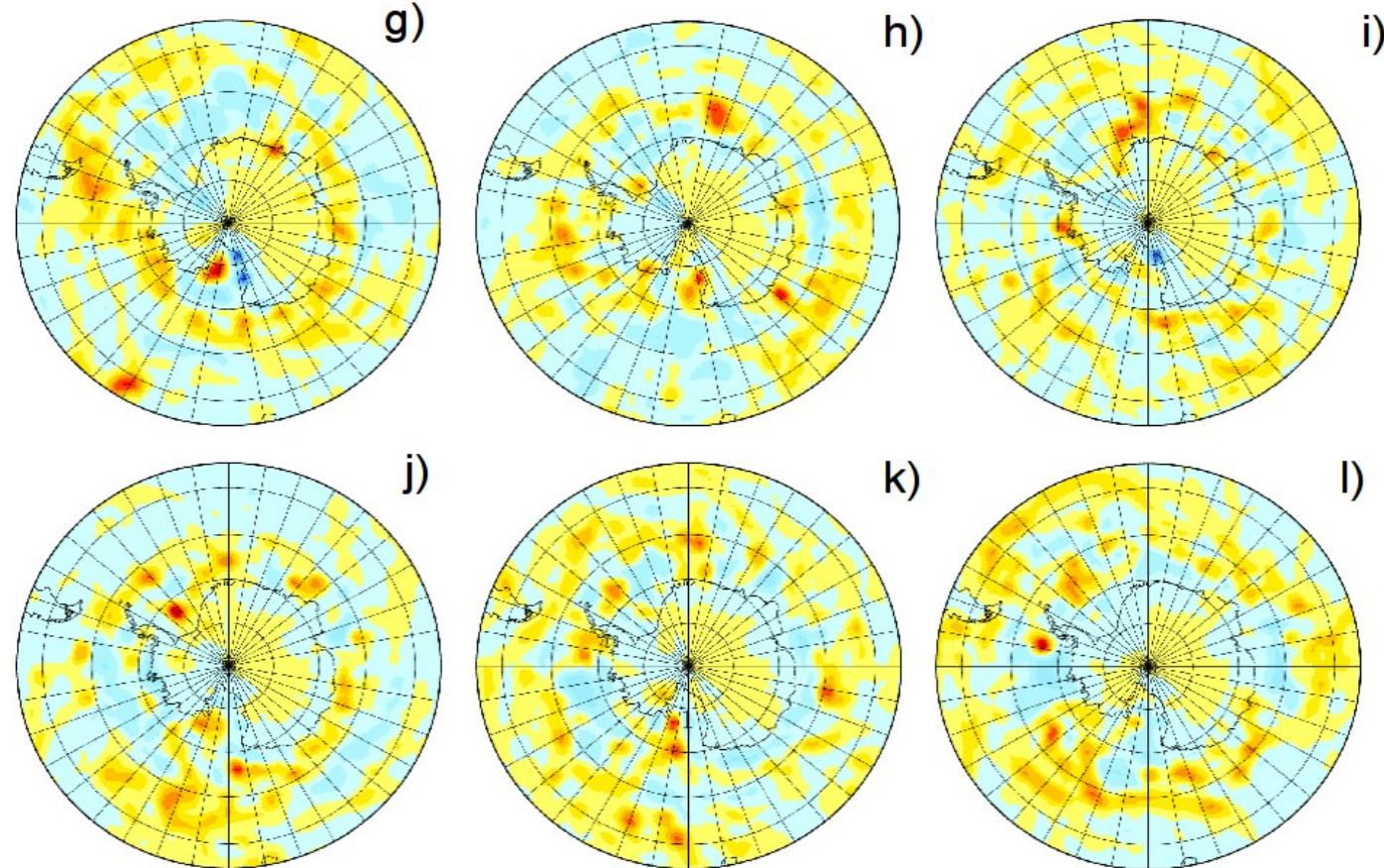

k)

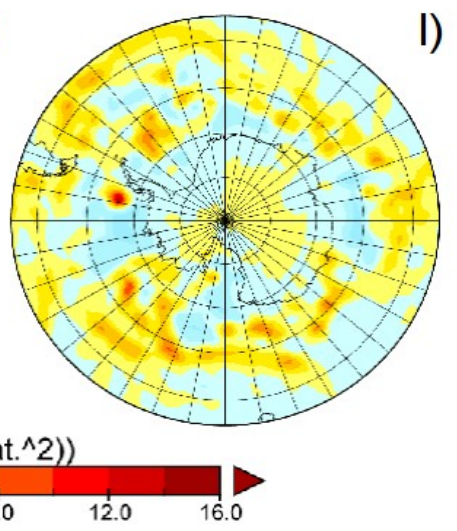

Fig. 8: Monthly (a) Jan - I) Dec 2012) anomalies of cyclone system density compared to the 1979 - 2015 mean derived from ECMWF reanalysis. 

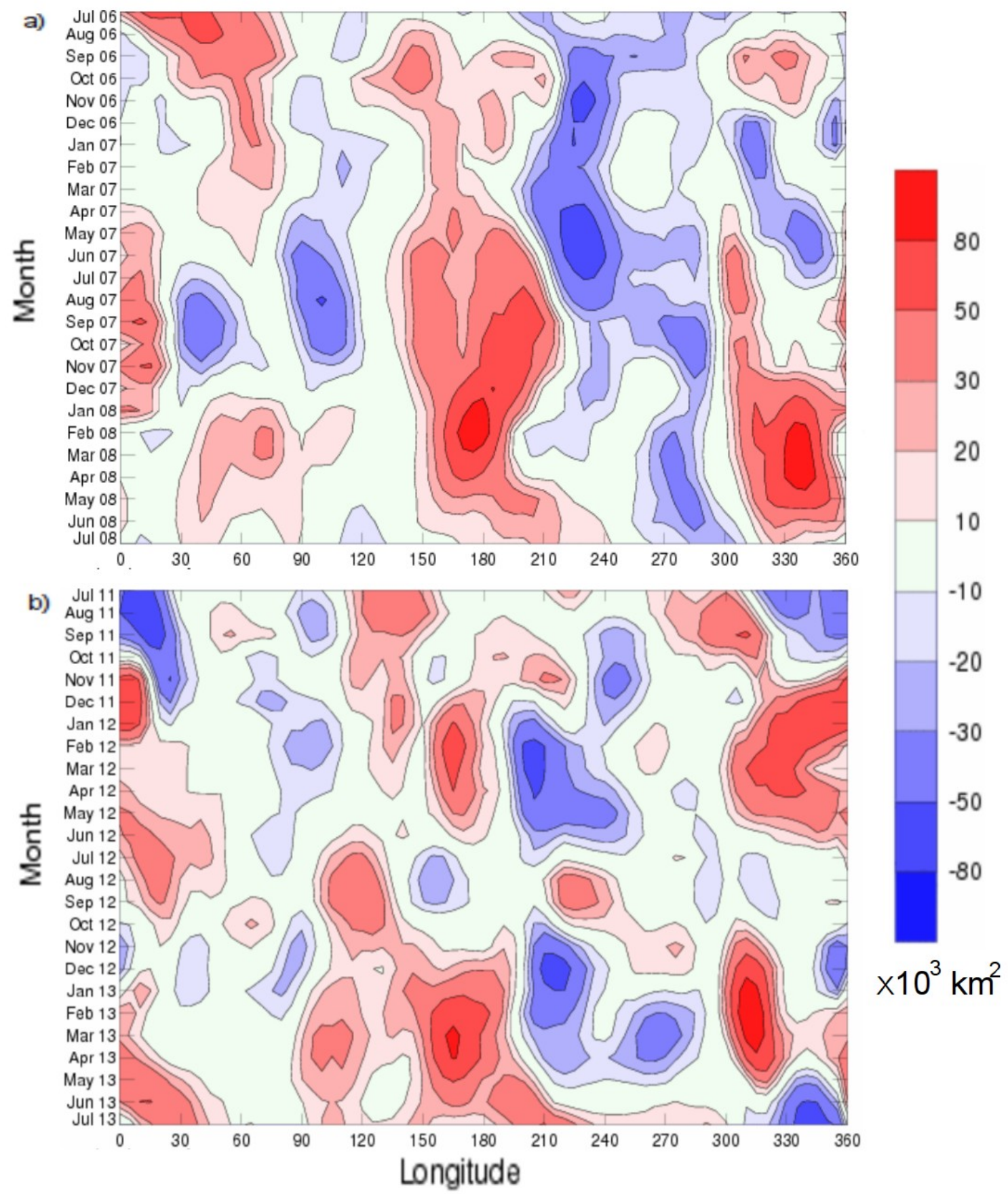

-20
-30
-50
$\mathrm{~km}^{2}$

Fig. 9: Hovmoeller diagrams of sea-ice extent anomalies centered on SIPEX 2007 (a) and SIPEX 2012 (b). 